\title{
Performance of Portfolios Composed of British SRI Stocks
}

\author{
Janusz Brzeszczynski * \\ Heriot-Watt University, Edinburgh, United Kingdom
}

\section{Graham McIntosh}

Heriot-Watt University, Edinburgh, United Kingdom

* Corresponding author: Department of Accountancy, Economics and Finance, Heriot-Watt University, Edinburgh, United Kingdom; tel.: +441314513294; fax: +441314513296; e-mail: j.brzeszczynski@hw.ac.uk. 


\title{
Performance of Portfolios Composed of British SRI Stocks
}

\begin{abstract}
:
This study investigates performance of portfolios composed of British Socially Responsible Investments (SRI) stocks. Using the Global 100 Most Sustainable Corporations in the World list (known also as: Global-100) to select the SRI companies, we found that, in the period 2000-2010, the returns of the SRI portfolios were on average higher compared to the corresponding returns of the market indexes. The annual average difference in returns of the SRI portfolios (with dividends) was 5.26\% and 5.69\% relative to the FTSE100 and FTSE4GOOD indexes (the total return versions), respectively, but the differences in returns in the whole period, in individual years and in other sub-periods were in most cases not statistically significant. Positive performance of SRI stocks in the whole sample is, however, evidenced by risk-adjusted measures such as the modified Sharpe ratio (MSR) and Certainty Equivalent (CEQ) returns, as well as by incorporating various levels of transaction costs. Moreover, a simple trading strategy relying on selection of SRI stocks from the Global-100 list would beat the market indexes in the whole period 2000-2010, even after inclusion of various levels of transaction costs. We also estimated the Fama-French and Carhart multi-factor models and found that the returns of the SRI portfolios cannot be consistently explained by conventional factors other than the market factor.
\end{abstract}

Keywords: Corporate Social Responsibility (CSR), SRI Stocks, Sustainable Investments, Stock Market Returns, London Stock Exchange (LSE). 
List of abbreviations:

CAPM - Capital Asset Pricing Model

CSP - Corporate Social Performance

CSR - Corporate Social Responsibility

DY - Dividend Yield

GBP - British Pound

LSE - London Stock Exchange

PE - Price-to-Earnings Ratio

SR - Socially Responsible

SRI - Socially Responsible Investments

WEF - World Economic Forum 


\section{Introduction}

Socially responsible investment (SRI), also known as ethical, sociallyconscious, or sustainable investment, refers to an investment strategy that seeks to combine social and/or environmental benefits with financial return, thus linking an investor's social, ethical, ecological and economic concerns. In many cases, investors are willing to sacrifice financial gains if, through their investments, better social or environmental benefits can be achieved.

There is considerable debate as to what truly constitutes SRI (see e.g. Cowton, 1994, 1998 and Sparkes, 1995, 2001). This study uses the term "socially responsible” to be interchangeable with "sustainability" and to include social, environmental, ethical and governance aspects of financial investment activity.

SRI developed mainly from environmentalism as environmentally conscious individuals looked for a way to align their investments with their beliefs (Statman, 2008). Historically, religious institutions have been at the forefront of SRI (e.g. Kinder et al., 1994, Sparkes, 1995 and Kreander et al., 2004). However, the modern SRI movement emanated from the political climate in the 1960s (Schueth, 2003 and Asongu, 2007). Rachel Carson’s 1962 book Silent Spring has been credited with launching the environmental movement (Halberstam, 2003 and Glausiusz, 2007) and SRI activists also focused attention on apartheid in South Africa in the 1960s through to the end of that regime in the 1990s. During the 1970s, concerns about the Vietnam War were also incorporated by SR investors (Lowry, 1991) and they later focused their attention on toxic waste, pollution and contamination (Asongu, 2007). The 1970s and later years have seen social and, sometimes, environmental problems being addressed by investors, who have used negative lists and exclusion criteria (Schaltegger and Figge, 2001). 
SRI is an area of growing importance, due to the increase of funds invested according to socially responsible criteria. It is estimated that almost one out of nine dollars under professional management in the USA is invested in such a way (Social Investment Forum, 2007) while by the year 2000 many institutional investors, such as pension funds managing as much as $78 \%$ of all pension assets in the UK, had incorporated social issues into their investment strategies (United Kingdom Social Investment Forum, 2000). With SRI becoming an important new style of investment, the performance of SRI stocks, funds and indexes is an area of major interest to both institutional and private investors.

A world-wide increase in the number and value of the SRI funds and the creation of various national or international SRI indexes, such as Merlin Ecology Fund, KLD's Domini 400 and the FTSE4GOOD series, means that SRI has also become a global movement. ${ }^{1}$ Sparkes and Cowton (2004) argue that the reason SRI has grown significantly is due to its adoption as an investment philosophy by an increasing proportion of large institutional investors. Major newspapers and magazines, such as the Financial Times, The Economist and Business Week, are increasingly publishing articles related to SRI. A study by Mercer Investment Consulting revealed a belief by money managers worldwide that the adoption of SRI practices and strategies would become commonplace (Ambachtsheer, 2005).

The empirical analysis of SRI stocks dates back to 1972 (see Moskowitz, 1972 and Bragdon and Marlin, 1972). It was later extended to evaluation of the performance of SRI indexes (e.g. Sauer, 1997, Schroder, 2007 and Consolandi et al., 2008) and SRI funds (e.g. Goldreyer and Diltz, 1999, Scholtens, 2005, Jones et al., 2008 and Humphrey and Lee, 2011). Research has also been conducted into the performance of portfolios constructed by using information from research analysts (Kempf and Osthoff, 2007). 
There has, however, been little or no investigation of the profitability of portfolios likely to be constructed by private investors, who use a wide array of different methods to select stocks. We investigate the performance of a strategy with SRI stocks which can be chosen by these investors based on sustainability criteria.

Various studies report that SRI stocks and SRI funds tend to either outperform or achieve returns at least equivalent to the performance of the market. These include Hamilton et al. (1993), Guerard (1997), Sauer (1997), Goldreyer and Diltz (1999), Statman (2000), Bauer et al. (2005), Derwall et al. (2005), Scholtens (2005) and Brzeszczynski et al. (2009). In particular, Kempf and Osthoff (2007) found that using the social responsibility ratings from KLD Research \& Analytics, a SRI portfolio can be constructed that can provide abnormally high returns, even after taking into consideration trading costs. However, because of the cost associated with obtaining the social responsibility ratings, such a strategy would only be available to investment funds, pension funds and institutional investors..

The aim of this paper is to examine whether a private investor investing in UK stocks can follow the SRI strategy without the need to access the type of expensive research documented in Kempf and Osthoff (2007) that can help to achieve abnormally high returns. Hence, in our study we make use of easily accessible and free information. We apply a very unique and new data set, not used in previous research: a list of the Global 100 Most Sustainable Corporations in the World, from which we select the SRI stocks. We construct portfolios composed of those stocks and simulate their performance by calculating raw returns, as well as risk-adjusted measures, which we compare with the stock indexes: the FTSE100 and the FTSE4GOOD UK. In addition, we investigate the possible explanations for the performance of these portfolios by estimating the parameters of multi-factor models of Fama and French (1992 and 1993) and Carhart (1997). 
The analysis in this paper contributes to the existing SRI literature by providing evidence about the profitability of private investors’ SRI portfolios from 2000 to 2010. This period encapsulates both bull and bear market phases, hence it allows assessment of the impact of both these market conditions on the profitability of SRI portfolios that can be constructed by those investors.

This study also addresses the deficiencies in the existing literature highlighted by Chegut et al. (2011), namely: data quality (taking into account dividends and transaction costs on the portfolio), social responsibility verification (verification through independent third party sources), survivorship bias (incorporating dead stocks into the analysis) and benchmarking (testing against several benchmarks, both conventional and socially responsible). We deal with these issues by including dividends, transaction costs and stocks that no longer trade in the analysis. The use of two benchmarks addresses the benchmarking deficiencies and the use of the Global100 list ensures third party verification.

The paper is organised as follows: Section 2 provides a review of the relevant literature, Section 3 discusses the data and describes the methodology, Section 4 presents empirical results and discussion of the main findings and the last section concludes.

\section{Literature Review}

Below, we discuss the theoretical arguments as well as the empirical findings reported in the literature on SRI stocks, SRI funds and SRI indexes, since all those three areas are strictly related to the subject of investigation in our study (i.e. the SRI portfolios are not 'funds' per se, but they can be viewed as an alternative to funds, in particular when they are constructed by private investors, and in this paper we also compare our results to the FTSE4GOOD, as a benchmark SRI index). In selecting 
literature for this review, we took into account rankings and classifications from the review work of Hoepner and McMillan (working paper) about the Influential Literature Analysis (ILA) based on their analysis of citations intensity of the relevant journal articles on responsible investment.

\subsection{Theoretical Arguments}

The existing literature presents conflicting theoretical arguments. The earliest ones date back to Milton Friedman, who stated that the social responsibility of businesses is to increase their profits and that they should avoid any social initiatives that eventually lead to the decrease of shareholder value (see e.g. the article from 'New York Times' from 13 September 1970 cited in: Humphrey et al. (2012)). However, more recent arguments from the 1980s and 1990s, i.e. those postulated by theories such as the instrumental stakeholders theory and the slack resources theory, predict a positive relationship between corporate social performance and financial performance. There are also new discussions motivated by behavioural finance issues (see e.g. Statman, 2005 and 2008).

Instrumental stakeholder theory postulates that companies aim to satisfy various stakeholder groups and that the resulting stakeholder-management relationships serve as monitoring and enforcement mechanisms leading to various positive effects, such as the increased efficiency of the firm's adaptation to external demands, as well as to better financial performance (Freeman and Evan, 1990, Hill and Jones, 1992, Jones, 1995 and Clarkson, 1995).

Slack resources theory argues, in turn, that positive financial performance allows companies to become more socially responsible because it provides the additional resources necessary to engage in corporate social responsibility, which 
usually requires availability of excess funds (Ullmann, 1985, McGuire et al., 1988 and Waddock and Graves, 1997).

More recent studies have presented theoretical models that explore the effects of exclusionary ethical investing on corporate behaviour in a risk-averse equilibrium setting (Heinkel et al., 2001) and explain under which conditions companies can increase their value by engaging in corporate social responsibility activities (Mackey et al., 2007).

In addition, other existing theories postulate that socially responsible companies are also likely to benefit from different "mediating effects", such as improvement of reputation, better relations with both financial institutions and investors as well as easier access to capital (Spicer, 1978, Fombrun and Shanley, 1990). Further positive consequences of reputational effects, such as increase in employees' goodwill, may also lead to improvement of the firm's financial performance (Davis, 1973, McGuire et al., 1988, Waddock and Graves, 1997).

On the other hand, there also exist arguments that investment in socially responsible stocks may lead to poorer financial results relative to the benchmarks or to non-SRI investments. Minor's (2007) study on the financial cost of SRI delves into the main three fundamental economic principles related to the performance of SRI stocks. Firstly, as also highlighted by Ali and Szyszka (2006), supply and demand theory implies that the demand for an unethical stock with equivalent financial performance relative to an ethical stock will increase its return, thus ensuring the SRI fund that rejected this stock suffers lower performance relative to conventional funds, which do not have any such ethical objections. Secondly, asset selection constraints will put restrictions on investment opportunities. This, in turn, will reduce diversification benefits and the expected return. Thirdly, there exist the so called externalities effects. For example, £1m of external costs due to a company’s pollution output reduces that 
company's profit to the SR investor but not to the conventional investor, so, by divesting it, the SR investor is likely to achieve a lower return.

In summary, there are theories which predict a positive relationship between corporate social performance and financial performance, however there exist also arguments that postulate certain limitations on performance of SRI stocks on the stock market.

\subsection{Empirical Studies}

Numerous empirical studies have been conducted in the area of SRI since the early study by Moskowitz (1972). The majority of these, including Anderson and Frankle (1980), Luck and Pilotte (1993), Epstein and Schnietz (2002) and Kempf and Osthoff (2007), among others, found a positive relationship between social responsibility and financial performance. Other studies, however less numerous, have reported that social responsibility has a negative effect on financial performance or presented mixed evidence (see Vance, 1975, Alexander and Buchholz, 1978, Mueller, 1991, Hamilton et al., 1993, Kurtz and Di Bartolomeo, 1996, Brown, 1997 and Gregory et al. 1997, among others).

Overall, the available evidence in the existing empirical literature can be summarised by the conclusions presented in the review of Orlitzky et al. (2003), that market forces generally do not penalise companies that are high in corporate social performance. This review, based on the meta-analysis of 52 studies which included a total sample size of 33,878 observations, concluded that in the majority of reported cases, corporate social performance tends to be positively related to financial performance.

The SRI literature can be grouped into three categories: those assessing individual stocks and author constructed portfolios, those assessing SRI funds and 
those assessing SRI indexes. The findings of these areas of research are discussed individually in the following sections (using chronological order as a main guiding principle), and then some explanations of the reported results are discussed.

\subsubsection{SRI Stocks and Portfolios}

One of the earliest key studies on the SRI stocks was Vance (1975), who found a negative relation between corporate social responsibility and change in stock prices, based on US data from 1974. Margolis and Walsh (2003) and Orlitzky et al. (2003) reviewed later a large number of studies, starting from the 1970s, covering the performance of SRI stocks and SRI portfolios (see e.g. Vance, 1975, Abbott and Monsen, 1979, Shane and Spicer, 1983, Patten, 1990, Blackburn et al, 1994, and Guerard, 1997, among many others).

Margolis and Walsh (2003) provided a summary grouping the previous studies by the relationship between social responsibility and financial performance. This review highlighted the very mixed findings of the empirical literature. Orlitzky et al. (2003) carried out a meta-analysis of the Corporate Social Performance (CSP) literature and found that CSP is positively correlated with Corporate Financial Performance, the relationship tends to be bidirectional and simultaneous and reputation appears to be an important mediator of the relationship. They included more measures of financial performance (such as return on assets, accounting rate of return and other measures of profitability) rather than simply the return on the stock. Overall, Orlitzky et al. (2003) concluded that market forces generally do not penalise companies characterised by high corporate social performance, so managers can afford to be socially responsible. They may actively pursue social responsibility because they can expect that the market will eventually reward them for it. 
Below we report findings from other more recent key studies published already after the Margolis and Walsh (2003) and Orlitzky et al. (2003) review articles.

Derwall et al. (2005) assessed performance based on a measure of economic value created relative to the waste generated by a company. Using the Innovest Strategic Value Advisors' corporate eco-efficiency scores, two portfolios were constructed, which differed in eco-efficiency,. The study, covering US data over the period 1995 to 2003, found that the high eco-efficiency portfolio provided substantially higher average returns than the low eco-efficiency portfolio. Differences in market sensitivity, investment style, or industry-specific factors could not explain the performance differential and the results remained significant for transaction costs up to 200 bps.

Kempf and Osthoff (2007) found that remarkably high abnormal returns of 8.7\% can be earned by investors following the simple long-short strategy that relies on buying high socially responsible performing stocks and selling short low socially responsible performing stocks. Kempf and Osthoff (2007), who used data about US stocks, also report that best-in-class screens remain significantly profitable, even with relatively high transaction costs.

Hill et al. (2007) examined SRI performance across three regions of the world and found that only the European portfolio outperformed the conventional benchmark in the short term (i.e., 3 years). No results were significant in the medium term (i.e., 5 years). The US and European portfolios outperformed in the long term (i.e., 10 years).

Consolandi et al. (2008) studied additions and deletions to the Dow Jones Sustainability Stoxx Index (DJSSI). Their results show positive (negative) excess returns for companies included in (deleted from) the DJSSI index.

Humphrey et al. (2012) investigated whether UK based firms’ corporate social performance ratings impact their performance and risk. Focusing on the period October 
2002 to May 2011, they found no difference in the risk-adjusted performance and idiosyncratic risk of firms with high and low CSP ratings.

Galema et al. (working paper) concluded that when considering the entire efficient frontier and not imposing any short-sales restrictions, socially responsible US investors are worse off in mean-variance terms for almost every theme they assess except governance. However, these investors suffer only in terms of foregone risk reduction opportunities, not in terms of foregone returns. In addition, when they introduce short sale constraints, investors are no longer worse off by investing socially responsibly.

\subsubsection{SRI Funds}

Goldreyer and Diltz (1999) studied the performance of SRI and conventional funds based in the USA over the period 1981 to 1997 and did not find an unambiguous performance advantage for either group. While conventional funds appear to outperform SRI funds in a larger number of circumstances, SRI fund performance equals or exceeds conventional fund performance in what they believe are many important cases, including arguably the most important situations.

Cummings (2000) also found insignificant differences in performance of SRI funds in Australia compared to conventional market indexes over the period 1986 to 1996 and Bauer et al. (2007) found similar results for Canadian funds for the years 1994 to 2003.

Scholtens (2005) concluded there was no difference in the risk-adjusted returns of SRI funds compared to conventional funds in the Netherlands. SRI funds in the Netherlands were found to outperform conventional funds, but the difference was not significant. When differences in market risk, size, style and momentum were accounted 
for, conventional funds had a somewhat higher return than SRI funds, but again this difference was not significant.

After adjusting for the degree of portfolio diversification, Bello (2005) found that, in the period 1994 to 2001, the investment performance of US socially responsible mutual funds was indistinguishable from that of conventional funds.

Bauer et al. (2005) applied a Carhart multi-factor model to assess mutual fund performance internationally (Germany, UK and USA). For the period 1990 to 2001 they find no evidence of significant differences in risk-adjusted returns between ethical and conventional funds, after controlling for investment style. They also suggest that ethical mutual funds underwent a catching up phase, before delivering financial returns similar to those of conventional mutual funds.

Mill (2006) found that mean risk-adjusted performance is unchanged by a UK conventional fund switching to SRI principles compared to similar funds whose investment criteria remained the same.

Bauer et al. (2006) compared a sample of 25 Australian SRI funds with 281 conventional funds. Using a four-factor model and conditional and unconditional onefactor models, they found that neither conventional nor SRI funds produce alphas ( $\alpha$ s) that are significantly different from zero. Hamilton et al. (1993) also found no statistically significant difference in performance when considering the risk-adjusted returns of a group of SRI funds from the US compared to unscreened funds.

Gregory and Whittaker (2007) found that neither UK SRI nor non-SRI funds exhibit significant underperformance on a risk/style adjusted basis. They show that performance appears to be time-varying and that conclusions on performance itself are influenced by whether a static or time-varying model is employed. Persistence in fund performance was investigated and they find evidence that supports persistence. They 
conclude "it is unambiguously the case that domestic past 'winner' SRI funds outperform 'loser' SRI funds at 36 month horizons on a risk-adjusted basis.”

Jones et al. (2008) reported results showing that Australian SRI funds significantly underperform. This conclusion was arrived at by investigating the performance of a portfolio of 89 SRI funds through examining $\alpha$ from both a one- and a four-factor market model.

Renneboog et al. (2008) studied the performance of SRI funds in 17 countries covering Europe, North America and the Asia-Pacific. They focused on the period 1991 to 2003 and found that SRI funds in the US, the UK, and in many continental European and Asia-Pacific countries underperform their domestic benchmarks. However, the risk-adjusted returns of SRI funds were not statistically different from the performance of conventional funds, with the exception of some countries such as France, Japan, and Sweden.

Cortez et al. (2009), using unconditional and conditional models, assessed the performance of SRI fund in seven European countries covering the period August 1996 to February 2007. The results show the funds exhibited neutral performance in relation to both conventional and socially responsible benchmarks. However, performance estimates seemed to be slightly higher when funds were evaluated in relation to SRI indices.

Gil-Bazo et al. (2010) found that US SRI funds obtained a higher after-fee riskadjusted performance than similar conventional funds. They also discovered that performance of SRI and conventional funds run by the same management company did not differ significantly, suggesting that "differences between SRI and conventional funds may be explained by management company-level factors that determine both fund performance and the company's decision to manage SRI funds.” SRI funds managed by generalist companies were found to actually underperform similar 
conventional funds, although the difference is not highly statistically significant in all specifications. SRI funds run by specialised management companies significantly outperform comparable conventional funds by more than $2.6 \%$ annually.

Humphrey and Lee (2011) found no significant difference in the returns of SRI portfolios compared to conventional funds in their study of Australian SRI funds.

Climent and Soriano (2011) applied a CAPM-based methodology to assess the performance of environmental funds, rather than the more general SRI funds, compared to their conventional peers. In a study of United States based funds, they found environmental funds had lower performance for the period 1987 to 2009 compared to conventional funds with similar characteristics. However, for the period 2001 to 2009, they found returns did not differ significantly between environmental funds, the remaining SRI funds and conventional funds.

\subsubsection{SRI Indexes}

Sauer (1997) compared returns of the Domini Social Index (DSI) to those of the S\&P 500 and CRSP Value-Weighted Market Indexes from 1986 through to 1994. He found that the DSI underperformed both benchmarks on a risk-adjusted basis for the period January 1986 to April 1990. However, when these backtest results were combined with the DSI's live performance for May 1990 to December 1994, aggregate risk-adjusted returns exceeded those of both conventional benchmarks. Statman (2000), however, reports that the performance of the Domini Social Index was similar to the performance of the S\&P 500 Index over the years 1990 to 1998.

Schroder (2007) found that 29 international SRI indexes exhibit no over- or under-performance compared to conventional indexes. Such investments, by being based on indexes instead of investment funds, exclude transaction costs, managers' 
skill and selection process costs that could affect the findings, so the pure performance of SRI relative to conventional investment could be assessed.

Consolandi et al. (2008) investigated the Dow Jones Sustainability Stoxx Index (DJSSI) in the period after the inception of the index, 2002 to 2006. They found that the performance of the DJSSI slightly outperforms the benchmarks.

Using SRI indexes and conventional stock indexes in the US, the UK and Japan, Managi et al. (2012) estimated first and second moments of firm performance distributions based on the Markov Switching (MS) model. No statistical difference in mean returns and volatilities of the SRI indexes and conventional indexes were found. Furthermore, they evidence strong co-movements between these indexes.

\subsection{Explanations for Empirical Findings}

In addition to reporting a broad range of empirical results, the existing literature often seeks to explain these findings relative to the theoretical predictions. For example, Orlitzky et al. (2003) find that stakeholder mismatching, sampling error and measurement error can explain between $15 \%$ and $100 \%$ of the cross-study variation in various subsets of CSP and CFP correlations.

In regard to Jones et al. (2008) attributing the underperformance to the fact that the funds are SRI, Humphrey and Lee (2011) point out that "the underperformance may not be because the investments are SRI funds, but rather that they are simply managed funds” and cite Jensen (1968), Ferson and Schadt (1996), Ferson and Warther (1996) and Carhart (1997) as evidence that managed funds do not appear able to outperform broad market indexes. They suggest that heterogeneity of the SRI funds that comprise the sample of Jones et al. (2008) may be a further reason for their finding. Humphrey and Lee (2011) point out that "as they only employ equity benchmarks, it is difficult to 
know whether the negative $\alpha$ s from their one- and four-factor models indicate underperformance or they are due to an incorrectly specified performance model.”

Minor (2007) proposes an explanation for why SRI portfolios can exhibit higher returns: that the SRI fund managers are more skilled than conventional fund managers. Fund manager skill is particularly relevant to the findings of Kempf and Osthoff (2007), as the manager would have had to have the skill to choose the investment strategy that resulted in those abnormally high returns. However, Ali and Szyszka (2006) found no evidence to support the hypothesis that SRI managers have undergone a learning curve which would result in them having superior skills.

Gil-Bazo et al. (2010) suggest that restricting the universe of available stocks could actually be a reason for SRI exhibiting higher returns than conventional investments: "The large size of the investment universe faced by fund managers implies that they must make choices about the breadth and depth of their analysis. Restricting the investment universe may prove optimal if depth is relatively more profitable than breadth" (Gil-Bazo et al. (2010)). Support for this hypothesis is provided by evidence that shows fund families following more focused investment strategies and mutual funds holding portfolios concentrated in specific industries tend to perform better (e.g. Nanda et al., 2004 and Kacperczyk et al., 2005).

The literature, particularly Orlitzky et al. (2003), seems to have established a positive link between social responsibility and financial performance, however Chegut et al. (2011) find there are still deficiencies in regard to assessing SRI performance that need to be addressed. Reviewing the SRI performance literature to develop best practice in the field, they identify five themes that require specific attention. These are: data quality, dividends and fees, social responsibility verification by independent third parties, survivorship bias, benchmarking and sensitivity and robustness checks. We address those issues in our study. 


\section{Data and Methodology}

\subsection{Database}

In this study we analyse the performance of portfolios composed of SRI stocks from the UK stock market over the period of years from 2000 to 2010 . We selected the UK SRI companies from the list of the Global 100 Most Sustainable Corporations in the World (known as: the Global-100), which provides classification of international socially responsible firms. The Global-100 is a project initiated by Corporate Knights Inc. with research powered by Innovest Strategic Value Advisors Inc. Launched in 2005, the annual Global-100 is unveiled each January during the World Economic Forum (WEF) at Davos, and it is free to access. The Global-100 companies are socially responsible in the sense that they have displayed a better ability than most of their industry peers to identify and effectively manage material environmental as well as social and governance factors.

According to the Global-100's website (www.global100.org) the intended audience for the Global-100 is everyone: from investors looking for self-enlightened companies that plan to be around for the long-haul to citizen groups that want to know which companies they may be able to work with in meaningful ways. This data also, therefore, fits the use of private investors applying the Global-100 list to derive stocks to include in their SRI portfolios, since it is likely that such individual investors will use this list in their stock selection.

Table 1 presents constituent companies selected each year in the period 20002010 for the SRI portfolios used in this study. It also shows the number of companies in the Global-100 list broken into numbers for each year and illustrates the decreasing trend of the presence of UK stocks. ${ }^{2}$ 
It can be seen in Table 1 that period 2000-2005 contains the same companies because the 2005 list was extrapolated backwards since the Global-100 list was first published and was available only from the year 2005.

SRI stocks selected for the portfolios analysed in this study belong to a broad range of industries. Their distribution is quite widely dispersed across the FTSE sectors, although not every sector is represented in the SRI portfolios.

In this paper we use two indexes, the FTSE100 and FTSE4GOOD (the UK version), for comparison with the returns achieved by the SRI portfolios. We compare the results of the investment in SRI portfolios with the 'price index' (PI) versions of the FTSE100 and FTSE4GOOD, which are the commonly accepted benchmarks. However, since the SRI portfolios include dividend payments, and this is what investors holding them would experience in reality and receive as an income from investing in these stocks, we also analyse returns of SRI portfolios against the 'total return index' (TRI) versions of the FTSE100 and FTSE4GOOD indexes (i.e. the versions which include dividend payments), so that the comparison is performed on an equal ground. On the other hand, the 'total return' versions of these indexes are not commonly used by investors as conventional benchmarks, so we also perform additional direct comparison between the 'price index' versions of the FTSE100 and FTSE4GOOD and the SRI portfolios without dividends, which again levels the playing field for this analysis.

The FTSE100 is the most important index of the London Stock Exchange (LSE) and it is defined as a market-capitalisation weighted index representing the performance of the 100 largest UK-domiciled blue chip companies, which pass screening for size and liquidity. The FTSE4GOOD index has been designed to measure the performance of companies that meet globally recognised corporate responsibility standards (www.ftse.com). The criteria of entry to the FTSE4GOOD index are revised 
regularly to remain consistent with market expectations and developments in CSR practice. These criteria are developed using an extensive market consultation process and are approved by an independent committee of experts. The FTSE4GOOD index was launched in July 2001; however, Datastream provides the backcasted values of this index (extrapolated backwards to July 1996), thus enabling the SRI portfolios' performance to be compared to the FTSE4GOOD over our entire sample period. Comparing the SRI portfolios' returns to the FTSE100 allows the performance to be assessed relative to conventional investment strategies, while comparing their returns to the FTSE4GOOD allows the performance to be assessed relative to a more appropriate index for the trading strategy analysed in this paper. The performance of the SRI portfolio relative to the FTSE100 would be of more interest to conventional investors whereas SR investors may be more interested in the performance relative to a socially responsible index such as the FTSE4GOOD.

The differences between inclusion criteria for the Global-100 list and for the FTSE4GOOD index are discussed in more detail later, in section 4.6.3.

\subsection{Methodology}

The Global-100 list was used to construct portfolios of UK socially responsible companies over the period from 2000 to 2010 (a total of ten annual sub-periods) and their returns were compared to the returns of the indexes. A company was considered UK based when its country on the Global-100 was either assigned as United Kingdom or as Great Britain.

The Global-100 list is announced at the end of January each year, right before the meeting of the World Economic Forum (WEF) in Davos, therefore it was assumed the first portfolio was constructed on the $1^{\text {st }}$ of February 2000. The portfolios were then rebalanced each year on the last working day of January. 
The selection procedure of stocks entering the portfolios was very straightforward. All the UK companies in the Global-100 entered the portfolio in the first year and the portfolio was held until the next Global-100 list was announced, a year later. Stocks that no longer appeared on the Global-100 were removed from the portfolio and those UK companies new to the Global-100 list were included. This procedure was repeated every year until the last year in the sample period.

As the Global-100 is an unranked list rather than an index, it is assumed that each stock has an equal weighting in the SRI portfolios. ${ }^{3}$ This means that where a stock remains in the portfolio from one year to the next, if the total number of stocks in the portfolio changes, a certain amount of that stock either has to be bought or sold to maintain the same weights.

When a company was taken-over and, in consequence, disappeared from the stock market in the period of duration of any of our portfolios, it was assumed that the proceeds were kept in a non-interest bearing account until the portfolio was rebalanced. The reason for such an assumption is that private investors are less likely to insist on reinvesting the proceeds and may simply keep the proceeds in their current account until the portfolios are rebalanced. When mergers or takeovers involved payment in stocks rather than cash, it was assumed that the new stocks were held in the proportion of the offer until the rebalancing event.

The price data has been gathered through Datastream. It is important to emphasise that the dividend data was also collected and the dividend payments were included in the analysis of the SRI portfolios’ performance. When the dividends were paid in a foreign currency, they were converted into GBP using the prevailing exchange rate at the time of the dividend payment. Dividends were added to the returns in the actual month they were paid when, according to the ex-dividend date, the investor was entitled to them. When dividends were paid but the stock was not held at the ex- 
dividend date, the dividend was not accounted for. When the ex-dividend date entitled the investor to a dividend but the stock was disposed of before the payment date, the dividend was accounted for. When there were takeovers and mergers involving companies in the SRI portfolio the necessary information was acquired through Datastream.

Similarly to the approach of Kempf and Osthoff (2007), the returns of the SRI portfolios were compared to the returns of the market indexes. The annual simple holding period returns for the SRI portfolios in two versions (with dividends and without dividends) as well as for the following indexes: FTSE100 (price index), FTSE100 (total return index), FTSE4GOOD (price index) and FTSE4GOOD (total return index) were calculated for all ten individual years and average annual geometric returns were computed for five-year sub-periods and the overall ten-year period. In addition, returns are analysed in other sub-periods which cover: (1) macroeconomic business cycles (growth and recession phases) and (2) stock market phases (bull and bear market periods). The results in these sub-periods allow for a deeper analysis of the performance of SRI portfolios and for further robustness checks to be performed. The annual return was determined as a simple holding period return with any dividends added, if the ex-dividend days were identified on any day within the investment period. For the one-, five- and ten-year periods, the average annual geometric returns using the annual data were calculated. For other sub-periods, returns were calculated using monthly data and then annualised to make them comparable with other periods. Whether the differences between returns on the SRI portfolio and the indexes were statistically significant was assessed by a $t$-statistic.

We also analysed the performance of the SRI portfolios by using the most important risk-adjusted measures, such as the modified Sharpe ratio of Israelsen (2005) and the Certainty Equivalent returns (see, e.g., DeMiguel et al., 2009), which were 
calculated for both versions of the SRI portfolios (with and without dividends) and both versions of FTSE100 and FTSE4GOOD indexes (total return indexes with dividends and price indexes without dividends). Their values were analysed to investigate whether risk can explain the difference or similarity in returns.

The Sharpe ratio (Sharpe, 1966 and 1994) measures excess return per unit of total risk. However, the classical definition of the Sharpe ratio suffers from inaccuracy errors and incorrect assessment of risk when returns are negative in some sub-periods, so we calculated the modified Sharpe ratio (MSR) of Israelsen (2005):

$$
M S R=E R / S D^{(E R / a b s E R)}
$$

where $E R$ is the excess return, defined as mean monthly difference between the portfolio (or index) return and the risk-free return, computed for n equal to 12, 60 or 120 months, and $S D$ is the sample standard deviation of the monthly differences of returns. The risk-free rate for the United Kingdom market used was the return of the UK Treasury Bill obtained from Xfi Centre for Finance and Investment at the University of Exeter (see Gregory et al., 2009 and 2011). ${ }^{4}$

MSR is a commonly used measure to deal with the problem of negative returns and alleviates the problems with the traditional Sharpe ratio.

Certainty Equivalent $(C E Q)$ returns are defined as:

$$
C E Q=\hat{\mu}_{k}-(\gamma / 2) \hat{\sigma}_{k}^{2}
$$

where $\hat{\mu}_{k}$ and $\hat{\sigma}_{k}^{2}$ are the mean and variance of excess returns of a portfolio or an index $k$ and $\gamma$ is the risk aversion parameter. As in the case of the modified Sharpe ratio $(M S R)$, the risk-free rate was the return of the UK Treasury Bill obtained from Xfi Centre for Finance and Investment. The formulation of CEQ in (2) assumes a multiperiod investor with quadratic utility. The 'normal' level of risk aversion is $\gamma=1$, while higher (lower) values of $\gamma$ indicate higher (lower) levels of risk aversion. ${ }^{5}$ 
In this paper we also assess whether trading costs could explain the excess return generated by the SRI portfolios, or lack of it. If a trading strategy generates outperformance of, say, $1 \%$ but additional trading costs reduce the outperformance to zero then it could be considered that the strategy's outperformance is only due to extra returns to compensate for greater trading costs. We follow the idea of Visscher and Filbeck (2003) and Brzeszczynski and Gajdka (2008) and calculate the percentage returns from investing 100,000 units of the domestic currency, in this case British Pounds (GBP), in the year 2000 and reinvesting the portfolio's wealth each year for ten years and performing ten rebalancing operations for the SRI portfolios until the year 2010. We take account of trading costs by using the following round-trip levels for the SRI portfolios and for the indexes: $0.00 \%, 0.50 \%, 1.00 \%, 2.00 \%, 3.00 \%$ and 4.00 . These rates can be considered to correspond to the trading costs of various groups of investors and their respective transaction sizes and take account of the fact that, in practice, the investor will incur higher expenses of trading in small sizes, either for rebalancing purposes or for re-investing dividends. The lower rates for the indexes reflect the fact that trading costs will be lower for investing in an index tracker fund/portfolio.

The reason for assessing the impact of trading costs, in addition to explaining the difference in returns relative to the indexes, is that it is often argued that outperformance of trading strategies is not meaningful unless it compensates for the costs involved (e.g. Keane, 1983 or Malkiel, 2003). Furthermore, Elton and Gruber (1995) suggest that many investment strategies presented in the literature as profitable are not so after inclusion of costs of trading. Therefore, for the SRI strategy to be of any significance to a private investor, it must be profitable after taking into account the costs involved. 
We analyse performance of SRI portfolios using a broad range of possible transaction costs because, in practice, the cost of trading can vary greatly among investors, depending on the size of transactions and the amount of capital which they invest. Hence, we provide a "stress test" of immunity of SRI portfolios performance to different levels of transaction costs.

Finally, we estimate parameters of the Fama-French three-factor model (Fama and French, 1992 and 1993):

$$
R_{p t}-R_{f t}=\alpha_{p}+\beta_{1 p} R M R F_{t}+\beta_{2 p} S M B_{t}+\beta_{3 p} H M L_{t}+\varepsilon_{p t}
$$

and the Carhart (1997) four-factor model:

$$
\begin{aligned}
R_{p t}-R_{f t}=\alpha_{p}+\beta_{1 p} R M R F_{t}+\beta_{2 p} S M B_{t} & +\beta_{3 p} H M L_{t}+ \\
& +\beta_{4 p} M O M E N T U M_{t}+\varepsilon_{p t}
\end{aligned}
$$

where $R_{p t}$ is the return on the SRI portfolio in period $t, R_{f t}$ is the risk-free return in period $t, R_{m t}$ is the return on the overall market in period $t$ and $R M R F_{t}=R_{m t}-R_{f t}, S M B_{t}$ is the difference in return between small-cap and large-cap portfolios in period $t, H M L_{t}$ is the difference in return between high book-to-market stocks (i.e. value stocks) and low book-to-market stocks (i.e. growth stocks) in period $t, M^{\prime}$ MENTUMt is the difference in return between portfolio of stocks classified as those that have strong momentum and stocks classified as those that have weak momentum and $\varepsilon_{p t}$ is the error term.

Fama-French and Carhart models are commonly applied as benchmarks in studies of SRI funds and SRI portfolios, as well as other broadly understood socially responsible investments, and they are used as a tool to explain their returns (see recently e.g. Renneboog et al. (2008), Gil-Bazo et al. (2010), Edmans (2011), Humphrey et al. (2012), among many others).

The data for the explanatory variables used in models (3a) and (3b) for the UK market, i.e. for $R_{f t}, R_{m t}, R M R F_{t}, S M B_{t}, H M L_{t}$ and $M O M E N T U M_{t}$, were obtained directly 
from the Xfi Centre for Finance and Investment (a detailed explanation of all data and the methodology used for construction of these variables can be found in: Gregory et al., 2009 and 2011).

In the next section, we present the analysis of raw returns and assess the performance of the SRI portfolios relative to the FTSE100 and the FTSE4GOOD indexes. In addition, we attempt to explain the SRI portfolios' returns by assessing the risk-adjusted measures, incorporating transaction costs and also by estimating FamaFrench and Carhart multi-factor models.

\section{Empirical Results and Discussion}

\subsection{Raw Returns}

In Tables 2a - 2c we present first the annual returns and average annual geometric returns ${ }^{6}$ for multiple-year periods and other sub-periods, based on the simulation of investment in the UK companies from the Global-100 list, compared to both the FTSE100 and the FTSE4GOOD indexes and also the values of the respective t-statistics. They show that the SRI portfolios have beaten both the FTSE100 and the FTSE4GOOD in most sub-periods and in the entire 10 year period from 2000 to 2010, although the differences in returns are not statistically significant in most cases. Table 2a shows that the SRI portfolios (with dividends) delivered returns which were higher by $5.26 \%$ than those of the FTSE100 total return index (with dividends) and by $5.69 \%$ than the FTSE4GOOD total return index (with dividends) in the entire period under investigation. It demonstrates also that the SRI portfolios have higher returns than both indexes in 4 out of 6 five-year periods: however, the differences were, again, not statistically significant in most of them. As a further robustness check, we analysed the returns in other sub-samples (which cover different phases of the business cycle, as well as bull and bear market periods). The SRI portfolios have consistently achieved 
higher returns than the benchmark indexes in all those cases. However, again, the differences were not statistically significant and the advantage of the SRI portfolios was often marginal.

Next we analyse the returns of the SRI portfolios against the price index versions of the FTSE100 and the FTSE4GOOD indexes, which are more commonly used as benchmarks than their total return versions. Table $2 \mathrm{~b}$ shows that, during the whole period, the advantage of the SRI portfolios increased to $8.58 \%$ against the FTSE100 and to 9.02\% against the FTSE4GOOD. The pattern of performance shows that the SRI portfolios have now beaten both indexes in all multiple-year periods.

The picture revealed in Table 2c showing the returns of the SRI portfolios without dividends against the price index versions of the FTSE100 and the FTSE4GOOD indexes, which do not include dividends, is similar to findings from Table 2a, but the positive performance in the whole period is reduced to $4.43 \%$ against the FTSE100 and to $4.87 \%$ against the FTSE4GOOD.

[Tables $2 a, 2 b$ and $2 c$ around here]

A noteworthy finding in Tables $2 \mathrm{a}-2 \mathrm{c}$ is that the SRI portfolios have performed better than both indexes by higher margins in the periods of economic recession than in the periods of economic growth but the outperformance in the bull and bear market periods on the stock market is very similar. This result is important for private investors, because a strategy that can offer consistently higher returns in bull markets and does not underperform in bear markets compared to the indexes would be exceptionally attractive, as it allows them to always gain in rising markets whilst not to underperform in declining markets, relative to the benchmarks. 
Comparison of returns for variants of the SRI portfolios with and without dividends has an additional benefit of the possibility of extracting the effect that the dividends of SRI stocks have on the total returns. In case of the SRI portfolios, the difference between average annual returns is $4.15 \%$ (and the contribution of dividends is more than $60 \%$ of the average annual return of $6.71 \%$ for SRI portfolios with dividends, as compared with that for SRI portfolios without dividends, which is only 2.56\%). The corresponding differences for the FTSE100 and FTSE4GOOD with and without dividends are: $3.32 \%$ and $3.33 \%$.

Below in section 4.2 we present further analysis of the performance of SRI portfolios against the indexes using the risk-adjusted measures only in the versions that reflect the outcome of actual investments, i.e. the analysis of the SRI portfolios with dividends (since dividends are an element of total income from investment in SRI stocks) versus the corresponding total return version of the indexes.

\subsection{Modified Sharpe Ratio (MSR)}

The values of the modified Sharpe ratio (MSR) are presented in Table 3, which shows that the SRI portfolios (with dividends) performed better than the FTSE100 and the FTSE4GOOD (total return versions) in seven out of the ten single-year periods and in the full period 2000 - 2010. In the whole period the MSR for the SRI portfolios is 0.067, while for both indexes it is negative at the -0.0001 level.

\section{[Table 3 around here]}

The SRI portfolios achieved higher values of the MSR measure than both indexes in 4 out of 6 multiple-year periods and in the sub-periods of recession and bear market. 
Good performance on the risk-adjusted basis, as measured by the MSR, resulted from the fact that the SRI portfolios offered better raw returns, even in the periods when the risk, as measured by standard deviation (see Table 3), was higher (which includes also the entire sample period from 2000 to 2010), it was more than compensated by the higher return, so the risk adjusted MSR ratio was often better, in such cases, for the SRI portfolios than the respective MSR ratio for the indexes. ${ }^{7}$

\subsection{Certainty Equivalent (CEQ) Returns}

The values of Certainty Equivalent (CEQ) returns for the SRI portfolios (with dividends) and the FTSE100 and the FTSE4GOOD indexes (total return versions) are presented in Table 4 for three variants, representing normal risk aversion of investors $(\gamma=1)$, lower risk aversion ( $\gamma=0.5$, i.e. half of normal risk aversion level) and higher risk aversion ( $\gamma=2$, i.e. double the normal risk aversion level). They show dominance of the SRI portfolios in most single-year periods and over the entire period for all the reported risk aversion levels. In the multiple-year periods the results are more mixed but still demonstrate good performance by the SRI portfolios, i.e. that they performed better than both indexes in case of the normal risk aversion level in 5 out of 6 five-year periods and in all other sub-periods. However, our findings also show that for more risk averse investors, the attractiveness of the SRI portfolios declines. ${ }^{8}$

\section{[Table 4 around here]}

Results in Tables 2a-2c, 3 and 4 also show that, although SRI portfolios offered higher returns in the periods of both economic recession and economic growth and in the bull and bear market periods, when risk adjusted measures are taken into account only in case of $C E Q$ returns they followed the same pattern. 


\subsection{Results of Investment Strategies and Analysis of Trading Costs}

It has been shown so far that the SRI portfolios achieved higher returns than the benchmarks over the entire period of the years 2000 - 2010, and in most single-year and multiple-year sub-periods, but the differences in returns usually were not statistically significant. However, the fact that there are only a small number of cases with statistical significance does not necessarily have to imply that there are no economic benefits from investing in such portfolios, if the positive performance (however large or small) is consistent over time.

Therefore, we now investigate the results of investment strategies which assume investment in the SRI portfolios at the beginning of the period in the year 2000 and re-balancing their composition every year until the end of our sample period in 2010. We calculated total returns of investment in SRI portfolios (in both variants: with and without dividends) and total returns of the benchmark buy-and-hold strategy for the indexes FTSE100 (price index), FTSE100 (total return index), FTSE4GOOD (price index) and FTSE4GOOD (total return index) over the whole period from 2000 to 2010. In addition, we also investigated whether costs of trading can justify their good performance and calculated the returns after adding different levels of transaction costs.

The returns that incorporate costs of trading are presented in Table 5. It can be seen that although the trading costs of $1 \%$ (round-trip) reduced the percentage returns obtained from $91.42 \%$ to $73.16 \%$ (for the SRI portfolio with dividends) and from $28.73 \%$ to $16.45 \%$ (for the SRI portfolio without dividends), these returns remain much higher than the corresponding returns of the benchmark buy-and-hold strategies for the indexes (14.41\% and 9.64\% for the FTSE100 and the FTSE4GOOD with dividends, 
respectively, and $-18.14 \%$ and $-21.74 \%$ for the FTSE100 and the FTSE4GOOD without dividends, respectively).

\section{[Table 5 around here]}

In terms of the possibility that trading costs might be explaining the excess return of the SRI portfolios over the indexes, Table 5 shows that, even if the costs involved in investing in the SRI portfolios were simulated at a very high level of $4 \%$, this factor alone cannot explain the advantage of the SRI portfolios.

In practice, in the UK market, typical transaction charges are in the region of 8.95 GBP to 12.50 GBP for purchasing the stock and then again for selling it, regardless of the value of the transaction. This gives round trip transaction costs in the range of $17.90 \mathrm{GBP}$ to $25.00 \mathrm{GBP}$ per stock for online accounts. Other methods of placing a trade, such as over the telephone, tend to incur higher transaction costs. In addition, investing an amount over a certain threshold may also attract additional trading costs. For example, some services levy an additional fee (e.g. 30 GBP) for trades placed with a value over 100,000 GBP. Clearly, then, the appropriate transaction cost percentage will depend on the amount of wealth that the investor has available to invest and, indeed, which broker the investor uses. For example, an investor with wealth that allows only 100 GBP to be placed into each of the stocks in the SRI portfolios will incur transaction cost in the region of $22 \%$ whereas for an investor whose wealth allows for 1,000 GBP to be placed into each stock it is roughly $2.2 \%$. For large institutional investors whose wealth and assets allow for investing 100,000 GBP in each stock, it is then only $0.02 \%$. In any case, the assumption of a typical round-trip transaction cost for the UK market at the level of around 1\% used in the example above can be treated as quite realistic, even for relatively small investors. 
In summary, we can conclude that transaction costs would need to be unreasonably high (or the value of traded stocks very small) in order to explain the difference in performance between the SRI portfolios (with and without dividends) and the corresponding indexes.

\subsection{Fama-French and Carhart Multi-Factor Models}

We now focus on the analysis of the Fama-French three-factor model and Carhart four-factor model, which are the most widely used multi-factor models for explaining performance of funds or stock portfolios.

\section{[Table 6 around here]}

Estimation of all models’ parameters was conducted using monthly frequency data (which is the interval of data for the Fama-French and Carhart factors in the database of the Xfi Centre for Finance and Investment at the University of Exeter). The market index used in the regressions was the FTSE All Share, which is a standard UK market benchmark used in the analyses of Fama-French and Carhart models in the UK market (also included in the Xfi Centre for Finance and Investment database).

In all regressions we tested for autocorrelation and heteroscedasticity of the error term. For autocorrelation we used Ljung-Box Q test and for heteroscedasticity, the Lagrange Multiplier (LM) test of Engle (1982). Heteroscedasticity was never detected in any period, so we estimated parameters of the Fama-French and Carhart models using the ordinary least squares (OLS) method. In cases when there was autocorrelation in any of the models, we removed it by relevant AR and/or MA terms.

Table 6 presents estimation results of parameters of the Fama-French threefactor model, represented by equation (3a). It shows that in the whole sample, only the 
market factor $R M R F_{t}$ is statistically significant and the other two variables, $S M B_{t}$ and $H M L_{t}$, are not. In the individual years, the $R M R F_{t}$ is significant in 8 out of 10 annual periods and it is also significant in all multiple-year periods. The $S M B_{t}$ and $H M L_{t}$ factors are significant only in one five-year period, in the years $2000-2005$ (and $H M L_{t}$ is also significant in the bear market sub-sample, however the estimate has the opposite sign).

The estimate of the $R M R F_{t}$ variable parameter (henceforth referred to as: beta) in the whole sample is statistically significant at the $1 \%$ level and equals 0.8604 . It is also very similar in all multiple-year periods (where it ranges from 0.7836 in period $2001-2006$ to 0.9478 in period $2004-2009$ ). A noteworthy result is that beta is always smaller than 1 in all multiple-year periods, suggesting that the SRI portfolios are less risky relative to the market. In single-years it is also almost always smaller than 1, whenever the estimate was statistically significant (except for one period, 2008 - 2009, when it marginally exceeds 1 and equals 1.0791).

Jagannathan and Wang (1996) demonstrate that the assumption of constant beta in the whole sample period is not reasonable, due to the (relative) risk of the firm, which may vary depending on factors such as the phase of business cycles. Hence, we further analyse beta in other sub-periods, such as: (1) macroeconomic business cycles (growth and recession phases) and (2) stock market phases (bull and bear market periods). ${ }^{9}$

Results in Table 6 show that the beta is very similar in magnitude in all four sub-periods of economic growth and recession and bull and bear market phases. ${ }^{10}$ Hence, the risk of SRI portfolios does not change substantially across the business cycles or stock market phases, although it is, indeed, somewhat higher in the recession periods rather than in the economic growth periods (the estimates of beta are 0.9020 and 0.8277, respectively) and in bear market rather than bull market periods (the 
respective estimates of beta are 0.8582 and 0.8284 ). In addition, the estimates of other variables $\left(H M L_{t}\right.$ and $\left.S M B_{t}\right)$ remain insignificant, as in the whole sample period, with the only exception of $H M L_{t}$ in the bear market (the estimate is 0.1272 and it is significant at the $5 \%$ level). ${ }^{11}$

Estimation results of parameters of the Carhart four-factor model represented by equation (3b) show that the momentum factor is not statistically significant in the whole sample period or in most multiple-year and single-year periods. Its inclusion in the model did not alter the overall picture, either, and other conclusions are very similar to the findings from the Fama-French model. ${ }^{12}$ The estimate of beta in the whole sample was statistically significant at the $1 \%$ level and equals 0.8580 . In the multiple-year periods it was also always significant and usually smaller than 1 , which confirms the pattern of results from the Fama-French model. ${ }^{13}$

It should also be emphasised that the estimates of alpha (the constant) in both Fama-French and Carhart models in the overall period and in most individual subperiods are not statistically different from zero. However, Table 6 demonstrates that there is a clear dominance of positive estimates over the negative ones and in some cases they were on the borderline of the significance at the $10 \%$ level (e.g. in the period 2003 - 2008 the p-value was 0.15 and even in the entire sample of years 2000 - 2010 it was still relatively low at the level of 0.24 ). In almost all cases except for one (period 2008-2009) estimates of alpha in Table 6 that were statistically significant are also positive. Hence, the returns offered by the SRI portfolios are higher than the sum of their expected return due to all equity risk factors from both Fama-French and Carhart models and such active strategy earns an additional (positive) return that cannot be achieved through simple indexing, but it is relatively small and not statistically significant in most of the reported periods. 
In summary, the estimation results of the Fama-French and Carhart models provide consistent evidence about the importance of market factor $R M R F_{t}$ and lack of significance of other factors $\left(S M B_{t}, H M L_{t}\right.$ and $\left.M O M E N T U M_{t}\right)$ in most multiple-year periods and most other sub-periods corresponding with business cycle phases and bull and bear market sub-periods, with evidence of relevance of these factors only in some of the shorter single-year periods.

\subsection{Possible Explanations of Differences in Performance}

In the following sections, we analyse the differences in returns between the SRI portfolios (in variants with and without dividends) and the FTSE100 and FTSE4GOOD indexes ('total return index' and 'price index' versions) and discuss them from the point of view of differences in construction rules and the composition of the Global100 list (as well as the resulting composition of the SRI portfolios) and the FTSE100 and FTSE4GOOD indexes. We also analyse whether the differences in performance between the two versions of SRI portfolios (with and without dividends) relative to the indexes can be explained by differences in the average value of dividend yield (DY) indicators for the portfolios and for these two indexes.

\subsubsection{Comparison of results between the SRI portfolios and the FTSE100}

The SRI portfolios yielded higher returns in all three comparisons to the FTSE100. A difference of $5.26 \%$ for SRI portfolios (with dividends) compared with the 'total return index' version; 8.58\% for SRI portfolios (with dividends) compared with the 'price index' version; and $4.43 \%$ for SRI portfolios without dividends compared with the 'price index' version.

The same pattern is observed in the risk-adjusted measures. The modified Sharpe ratios for the SRI portfolios are always higher than those for the FTSE100 over 
the whole period; however, the FTSE100 performs better than the SRI portfolios in some single-year and multiple-year sub-periods. This pattern is also evident in the case of the $C E Q$ returns.

The returns of the SRI portfolios, with and without dividends, are also substantially higher than the corresponding returns of the buy-and-hold strategies for the FTSE100 in both versions of 'total return index' and 'price index', respectively, even after inclusion of relatively high transaction costs.

Differences in performance between the SRI portfolios and the FTSE100 are possibly due to a different number of stocks, as well as to the different composition of those two sets resulting from different selection criteria. The FTSE100 is a broad market index that contains large stocks from a very broad range of industries which are not filtered using sustainability criteria while the Global-100 list and the resulting SRI portfolios, are constructed from stocks that are screened from the point of view of sustainability.

These differences in composition result in different values of the stock indicators usually used by investors to assess the attractiveness of a stock as an investment. For example, the average dividend yield (DY) for the SRI portfolios (calculated as the average DY for the entire period of 10 years from the time of new portfolio creation each February ) is 3.69\% and the corresponding DY for the FTSE100 index is $3.28 \%$. However, in the first half of the sample, in the years $2000-2004$, the average DY for the SRI portfolios was 3.86\% and for the FTSE100 only $2.85 \%$ and in the second half of the sample, in years 2005 - 2009, it was $3.53 \%$ and $3.70 \%$, respectively, so the DY has become higher later in the period for the FTSE100. This pattern is consistent with stronger performance of the SRI portfolios in the earlier subperiod. Moreover, the price-to-earnings ratio (PE) for the SRI portfolios and the FTSE100 follows a similar reversal pattern: the average PE in the years $2000-2004$ 
for the SRI portfolios is 18.70 while for the FTSE100 it is 21.18 but these averages in years 2005 - 2009 are, respectively, 16.60 and 11.81, so the difference in the average PE actually reversed over time in favour of the market index.

Hence, the values of the DY and PE indicators for the SRI portfolios and the FTSE100, as measures of attractiveness of stocks for investors, are related to the observed pattern of returns and to some extent explain the evolution of their differences over time. It can be further concluded that the SRI portfolios have performed better than the FTSE100 because their stocks may have been viewed by investors as more attractive investments relative to the average DY and PE indicators for the FTSE100 index.

\subsubsection{Comparison of results between the SRI portfolios and the}

\section{FTSE4GOOD}

One of the most interesting findings in this study, which is consistent across all tables with the results, is that the SRI portfolios have usually beaten the FTSE4GOOD index by a higher margin than their margin over the FTSE100 index, although, as stated earlier, not statistically significantly so.

In the case of the variants of the SRI portfolios with dividends and the 'total return' version of the FTSE4GOOD, the average annual geometric returns were $6.71 \%$ and $1.02 \%$, respectively; so the difference in performance is even higher than in case of the FTSE100 index: 5.69\% versus 5.26\%. When the SRI portfolios (with dividends) are compared with the 'price index' version the difference now increases from $5.69 \%$ to $9.02 \%$. The comparison of the SRI portfolios without dividends with the 'price index' version of the FTSE4GOOD yields the difference of $4.87 \%$.

In the case of the risk-adjusted measures, the modified Sharpe ratios for the SRI portfolios are again always higher than those for the FTSE4GOOD over the whole 
period and in the majority of single-year and multiple-year sub-periods. However, the comparison of both indexes shows that the FTSE100 outperforms the FTSE4GOOD in most single-year and multiple-year sub-periods. Hence, the FTSE4GOOD rarely delivered results that were superior to the FTSE100. As described above, this pattern is evident also in case of the CEQ returns.

The returns of the SRI portfolios, with and without dividends, are also substantially higher than the corresponding returns of the buy-and-hold strategies for the FTSE4GOOD index in both versions of 'total return index' and 'price index', respectively, even after inclusion of relatively high transaction costs. Again, these differences are larger when compared to the FTSE4GOOD rather than the FTSE100 (see Table 5).

As in the case of the comparison with the FTSE100 in the previous section, the values of the DY and PE indicators for the SRI portfolios and FTSE4GOOD are related to the observed pattern of returns and their differences over time. It is possible, therefore, that the SRI portfolios have outperformed both indexes because their stocks may have been viewed by investors as more attractive investments in relation to the average DY and PE for the FTSE100 as well as the FTSE4GOOD.

\subsubsection{Discussion of the differences in construction of the Global-100 list, the}

\section{SRI portfolios and the FTSE100 and FTSE4GOOD indexes}

The differences in performance between the SRI portfolios and the indexes are most likely related to the variations in composition between the Global-100 list (and the resulting subsequent choice of stocks for the SRI portfolios) and the FTSE100 and FTSE4GOOD indexes. The two main distinct differences are: (1) different number of stocks in the SRI portfolios and in the FTSE100 and FTSE4GOOD indexes and (2) different selection criteria for the Global-100 list and for the FTSE indexes, in 
particular for the FTSE4GOOD, which is directly comparable to the Global-100 list and the SRI portfolios analysed in this study.

The number of stocks in the SRI portfolios was determined by the composition of the Global-100 list and the number of British companies selected for inclusion in the Global-100 group each year. In the period of our analysis it ranged between 32 and 18, which was considerably fewer than the number of stocks in the FTSE100 and FTSE4GOOD indexes, i.e. 100 and 50, respectively.

However, although the Global-100 and the FTSE4GOOD have distinctly different criteria for selecting stocks they actually come to fairly similar conclusions about many companies. Between 50\% (2002-2003) and 71\% (2007-2008) of the United Kingdom based stocks on the Global-100 list are also in the FTSE4GOOD. The main criterion that differentiates the two is that the FTSE4GOOD ascertains its constituents by taking the 50 largest stocks by market capitalisation from approximately 300 stocks (this varies from year to year) that qualify for the index. Rather than using market capitalisation as the final step in selecting stocks the Global-100 uses its criteria of sustainability (discussed below) to identify its 100 worldwide stocks. The stocks listed as United Kingdom based then form the SRI portfolio. For example, in 2006-2007, 93\% of United Kingdom based stocks in the Global-100 were in the initial group of 280 stocks that the FTSE Group considered for inclusion in the FTSE4GOOD, showing there is not much difference in the outcome of the two selection methods.

Although the Global-100 list's initial universe is over 3500 companies, it tends to be comprised of the largest UK based companies. ${ }^{14}$ Between 66\% (2002-2003) and 94\% (2009-2010) of the constituents of the SRI portfolios are also members of the FTSE100 simply because the FTSE100 has twice as many stocks as the FTSE4GOOD. The SRI stocks that did not fall into the top 50 by market capitalisation for the FTSE4GOOD seem to fall into the top 100 for the FTSE100. As highlighted by 
Collison et al. (2009), the vast majority of the FTSE100 stocks qualify for inclusion in the FTSE4GOOD.

The FTSE4GOOD inclusion decision is made using information gathered from company questionnaire responses and direct contact, company report, company website and direct FTSE company engagement over new criteria (FTSE International Limited, 2010). The criteria are split into five main areas: environmental, human and labour rights, supply chain labour standards, countering bribery and climate change. Each of these broad areas is subdivided into three categories: policy, management and reporting (FTSE International Limited, 2010). Indicators are assigned to each of the policy, management and reporting subdivision: in some cases indicators are split between core and desirable. The number of indicators that a company must meet depends on whether that company is classed as high, medium, or low impact in that area. Collison et al. (2009) states in regard to the forms of words under the management category that they perhaps suggest a "procedural" rather than a "performance" orientation for the criteria. The FTSE Group also excludes companies that have been identified as having business interests in the following industries: tobacco producers, companies manufacturing either whole, strategic parts, or platforms for nuclear weapon systems and companies manufacturing whole weapons systems” (FTSE International Limited, 2010). The FTSE4GOOD is a market-weighted index and ranks companies according to their freefloat and liquidity adjusted market capitalisation (FTSE International Limited, 2010). So the top 50 companies that qualify for inclusion based on the criteria described above, ranked by capitalisation, constitute the FTSE4GOOD. The index is reviewed semi-annually in March and September.

The Global-100 has a different methodology for inclusion of companies. The Global Sustainability Research Alliance (GSRA) formed by Global Currents Investment Management and Phoenix Global Advisors LLC provides Corporate 
Knights Research Group and Inflection Point Capital Management with the top ten per cent of sustainability and financial performers from a universe of 3500 developed and emerging market stocks (Global 100, 2011). The GSRA covers 95\% of equities in North America, Europe and Korea and 30\% of equities in emerging markets (Global 100, 2011) and includes companies with capitalisations ranging from small to large. The top ten per cent are then assessed against ten equally-weighted Key Performance Indicators (KPIs) and a Transparency Indicator. The KPIs are in the following areas: energy productivity, water productivity, carbon productivity, waste productivity, safety productivity, CEO-to-average worker pay, taxes paid, sustainability pay link, leadership diversity and innovation capacity (Global 100, 2011). The result of this process is an unranked list of the top 100 most sustainable companies in world. The Global-100 criteria are predominately quantitative in nature whereas the FTSE4GOOD criteria focus on companies undertaking specific procedures. ${ }^{15}$

Hence, it can be concluded that the SRI portfolios based on the Global-100 list are more focused in terms of: (1) stocks size and (2) the more formal and more rigorous selection process compared to the FTSE4GOOD, due to not only a smaller number of companies, but also stricter and more quantitative (rather than qualitative) selection criteria, which most likely tend to identify the SRI stocks more rigorously than the broader FTSE4GOOD.

\subsubsection{Comparison of results between the SRI portfolios (with dividends) and}

\section{the SRI portfolios (without dividends)}

Finally, we attempted to explain the differences in performance between the two versions of the SRI portfolios: with and without dividends.

In this section we investigated further if the values of the dividend yield (DY) for the SRI portfolios differ significantly from the market averages and whether this 
difference may be responsible for the observed variation in returns of the SRI portfolios in variants with and without dividends.

We calculated first the differences between the dividend yield of the SRI portfolios and the FTSE100 and FTSE4GOOD indexes, along with their respective $t$ statistics. The results show that, over the whole period, the DY is higher for the SRI stocks than for both indexes (and it is also higher in most of the single-year and multiple-year sub-periods). ${ }^{16}$

Next we run the regressions for the models where the dependent variable is defined as the difference between returns of the SRI portfolios (with dividends and without dividends) and the independent variables are the difference in DY for the SRI portfolio and the FTSE100 and FTSE4GOOD indexes, respectively, defined as a ratio of those DY indicators:

$$
\operatorname{diff}\left(R_{p t}-R_{i t}\right)=\alpha_{p}+\beta_{p}\left(D Y_{p t} / D Y_{i t}\right)+\varepsilon_{t}
$$

where $R_{p t}$ are the returns of SRI portfolio (either in variant with or without dividends), $R_{i t}$ are the returns of the index (FTSE100 or FTSE4GOOD, either in variant with or without dividends, i.e. in their 'price index' or 'total return' versions) and $D Y_{p t} / D Y_{i t}$ is the ratio of dividend yields for the respective SRI portfolio and the index. Regression is performed using annual data for the whole period of analysis of $2000-2010$.

The results in Table 7 show evidence that the difference in returns is related to differences in dividend yield.

\section{[Table 7 around here]}

The estimates of the parameters for the $D Y_{p t} / D Y_{i t}$ variable are positive in all four cases (however, significant always at only the $10 \%$ level), which means that the difference in returns of the SRI portfolios is related proportionally to the difference in DY of the SRI 
portfolios and the market indexes. ${ }^{17}$ The results are stronger, however, for the FTSE4GOOD than for the FTSE100 (in terms of statistical significance, i.e. the estimates are significant at a higher level for the FTSE4GOOD and also because the $R^{2}$ is higher than the corresponding variants for FTSE100), which confirms earlier findings about better performance of the SRI portfolios with respect to the FTSE4GOOD rather than the FTSE100.

In summary, dividends (and, in particular, differences of the dividend yield as an indicator) seem to play a role in explaining the differences between the returns of the SRI portfolios and the stock market indexes: the FTSE100 and the FTSE4GOOD.

\subsubsection{Other possible explanations}

Other possible reasons for the performance of the SRI portfolios may be due to the SRI stocks containing the types of risks that are not measured by any of the factors considered above. However, it is reasonable to assume that such risk would be captured by, for example, standard deviation of stock prices, so it would be immediately evident in the values of the modified Sharpe ratio $(M S R)$ or the Certainty Equivalent (CEQ) returns.

Another possible reason for the pattern of the observed performance could be that the companies included in the Global-100 list were improving CSR through social, ethical and environmental initiatives and have also increased their profitability. Several authors have shown how improving CSR can induce positive performance and economic benefits (e.g. Lenssen et al., 2006, Ambec and Lanoie, 2008 and Neal and Cochran, 2008). Weber (2008) describes several potential business benefits of CSR: positive effects on company image and reputation, positive effect on employee motivation, retention and recruitment, cost savings and revenue increases from higher sales and market share. 
A further possible explanation for the difference in returns is that the Global100 may have included companies from exceptionally profitable industries. The fact that many industries are not represented in the SRI portfolios provides some support for this as the industries excluded may have been industries with poor stock performance. This would have dragged down the return of the FTSE100 but left the performance of the SRI portfolios unaffected. If this was the case, one would expect the FTSE4GOOD's performance to differ largely to the FTSE100 as it is unlikely that the FTSE4GOOD has a similar industry representation to the FTSE100. However, this is not the case as the performance of these two indexes is very similar, as highlighted by Tables 2a - 2c.

Finally, Mallin et al. (1995, p. 495) proposed a possible reason for the finding that SRI portfolios outperform the market and suggested that the superior performance may have been "a temporary phenomenon caused by an increased awareness and interest in ethical investment” and that this leads to an increased demand for SRI stocks which drives up their prices and increases the returns of the SRI portfolios. However, the SRI portfolios also have had a higher dividend yield (although this reversed over time, as we had mentioned previously). If prices are irrationally high, according to Shiller (2005), one would expect a low dividend yield. Therefore, it is not clearly obvious either that such herd behaviour can explain performance of the SRI portfolios.

\section{Conclusions}

The main objective of this study was to analyse the performance of SRI portfolios that can be constructed by private investors who could use freely available information about British SRI stocks. Previous evidence in Kempf and Osthoff (2007) showed that this was possible for investors who had access to expensive research 
(conducted by KLD Research \& Analytics). To address this objective this paper used the Global-100 list which is available free of charge at the www.global100.org website.

We find that in years from 2000 to 2010 the returns of the SRI portfolios, composed of British SRI stocks from the Global-100 list, were higher than the returns of both the FTSE100 and the FTSE4GOOD indexes, however the differences in returns between the SRI portfolios and both indexes were not statistically significant in most sub-periods and in the entire period of our analysis.

The annual average returns of the SRI portfolios (with dividends) were 5.26\% and 5.69\% higher relative to the benchmarks FTSE100 and FTSE4GOOD indexes (in their total return versions), respectively. Further comparison of returns for the SRI portfolios with and without dividends against the respective indexes, the FTSE100 and FTSE4GOOD, in their 'price index' (i.e. without dividends) and 'total return index' (i.e. with dividends) versions also demonstrates positive performance of the SRI portfolios. The annual average returns of the SRI portfolios (with dividends) were higher than the commonly used price index versions of the FTSE100 and FTSE4GOOD indexes by $8.58 \%$ and $9.02 \%$, respectively.

Positive performance of the SRI portfolios is confirmed using risk-adjusted measures such as the modified Sharpe ratio (MSR) and Certainty Equivalent (CEQ) returns as well as taking into account various levels of transaction costs.

We estimated also the Fama-French and Carhart multi-factor models and found that the returns of the SRI portfolios cannot be consistently explained by conventional factors other than the market factor.

It is also worthwhile to emphasise that the estimates of alpha (the constant) in both Fama-French and Carhart models in the overall period and in most individual periods were not statistically different from zero, which supports the results, evidenced also by the lack of statistical significance of returns differences. 
The portfolios presented in this study are equally-weighted, which is motivated by the fact that we intended to follow a simple investment strategy using the portfolios that can be constructed by private investors. We acknowledge that our findings may be affected to some degree by a stock size effect, however it is unlikely to be strong and materially change the overall picture which emerges from our results, due to the selection criteria of the Global-100 list, which is composed of mainly large stocks.

Although the differences in returns between the SRI portfolios and both indexes were not statistically significant in most sub-periods and in the entire period of our analysis, we show that a small number of cases with statistical significance does not necessarily have to imply that there are no economic benefits from investing in such portfolios, if better performance (however large or small) is consistent over time. We have presented results indicating that the SRI portfolios achieved substantially higher total returns than the benchmark buy-and-hold strategies for both indexes, over the entire period 2000 - 2010, even after including various levels of transaction costs.

This paper also sought to identify the reasons for the observed differences in performance between the SRI portfolios and the indexes. The most obvious possibility is an increased risk. However, as the SRI portfolios have been shown to achieve better results than the indexes using risk-adjusted measures, this is clearly not a valid explanation in this case. According to Keane's (1983) suggestion that a trading strategy's outperformance is not significant unless it can cover the costs of the strategy execution, we also investigated if trading costs may be able to explain the differences in performance. Even if annual trading costs were equal to $4 \%$ for the SRI portfolios and nil for the indexes this could not explain the observed performance patterns.

The findings presented in this paper cannot classify it into the stream of literature that evidences clear outperformance of the SRI portfolios relative to the market indexes. However, our results indicate that the SRI portfolios can beat the 
market indexes, in particular on the risk-adjusted basis and when they are used as a basis for construction of trading strategies, even if the differences in returns in individual years and in the whole period were in most cases not statistically significant. This is the main contribution of our research. The question remains, however, what drives the SRI stocks returns. We point towards an explanation related to the analysis of other stock market indicators, such as dividend yield (DY) and price-to-earnings ratio (PE), which are commonly considered to measure attractiveness of stocks for investors. Our findings suggest that both those variables are related to the observed patterns in differences of returns and their evolution over time. This opens a new avenue for future research.

We believe that another interesting route of research would be a comparison of performance of the SRI portfolios based on the Global-100 list across all countries, including a detailed investigation of their DY and PE ratios in relation to the average values of those indicators in their respective home markets. 
Table 1. List of companies in the SRI portfolios over the period from 2000 to 2010.

\begin{tabular}{|c|c|c|c|c|c|c|c|c|c|c|}
\hline Company & 2000-01 & 2001-02 & $2002-03$ & 2003-04 & 2004-05 & $2005-06$ & 2006-07 & 2007-08 & 2005-06 & $2009-10$ \\
\hline 3І Group & $\mathrm{x}$ & $\mathrm{x}$ & $x$ & $\mathrm{x}$ & $\mathrm{x}$ & $\mathrm{x}$ & & & $\mathrm{x}$ & \\
\hline Alliance Unichem & & & & & & & $x$ & & & \\
\hline Aviva & $x$ & $x$ & $x$ & $x$ & $x$ & $\mathrm{x}$ & $x$ & & & \\
\hline BAA & $x$ & $x$ & $x$ & $x$ & $x$ & $x$ & $x$ & & & \\
\hline BG Group & & & & & & & & & & $x$ \\
\hline Boots Group & & & & & & & $x$ & & & \\
\hline $\mathrm{BP}$ & $\mathrm{x}$ & $\mathrm{x}$ & $x$ & $x$ & $x$ & $x$ & $\mathrm{x}$ & & & \\
\hline British Airways & $x$ & $x$ & $x$ & $x$ & $x$ & $x$ & $x$ & $x$ & & \\
\hline British Land Co & $\mathrm{x}$ & $\mathrm{x}$ & $x$ & $x$ & $x$ & $x$ & $\mathrm{x}$ & $x$ & $x$ & $x$ \\
\hline British Sky Broadcasting Group & & & & & & & $x$ & $x$ & $x$ & $x$ \\
\hline BT Group & $x$ & $\mathrm{x}$ & $x$ & $x$ & $x$ & $x$ & $x$ & $x$ & $x$ & \\
\hline Cable \& Wireless & & & & & & & & $x$ & $x$ & $x$ \\
\hline Cadbury Schweppes & $x$ & $x$ & $x$ & $x$ & $x$ & $x$ & $x$ & & & \\
\hline Cairn Energy & $x$ & $x$ & $x$ & $x$ & $x$ & $x$ & & & & $x$ \\
\hline Cattles & & & & & & & & & $x$ & \\
\hline Centrica & $x$ & $\mathrm{x}$ & $x$ & $x$ & $x$ & $x$ & $x$ & $x$ & $x$ & $x$ \\
\hline David S. Smith Holdings & $x$ & $x$ & $x$ & $x$ & $x$ & $x$ & & & & \\
\hline Diageo & $\mathrm{x}$ & $\mathrm{x}$ & $x$ & $x$ & $x$ & $\mathrm{x}$ & $x$ & $x$ & $x$ & $x$ \\
\hline Electrocomponents & & & & & & & & $x$ & $x$ & \\
\hline Expro International Group & $x$ & $x$ & $x$ & $x$ & $x$ & $x$ & & & & \\
\hline George Wimpey & & & & & & & & $x$ & & \\
\hline GlaxoSmithKline & $\mathrm{x}$ & $\mathrm{x}$ & $x$ & $x$ & $x$ & $\mathrm{x}$ & $\mathrm{x}$ & & & $x$ \\
\hline GUS & $x$ & $x$ & $x$ & $x$ & $x$ & $x$ & $x$ & & & \\
\hline Hays & $x$ & $x$ & $x$ & $x$ & $x$ & $x$ & & & & \\
\hline HBOS & $\mathrm{x}$ & $\mathrm{x}$ & $\mathrm{x}$ & $\mathrm{x}$ & $\mathrm{x}$ & $\mathrm{x}$ & $x$ & $x$ & $x$ & \\
\hline HSBC Holdings & & & & & & & & $x$ & & \\
\hline J Sainsbury & $x$ & $x$ & $x$ & $x$ & $x$ & $\mathrm{x}$ & & $x$ & $x$ & $x$ \\
\hline Johnson Matthey & & & & & & & & $x$ & $x$ & \\
\hline Kingfisher & $x$ & $x$ & $x$ & $x$ & $x$ & $x$ & & $x$ & & \\
\hline Land Securities & $x$ & $x$ & $\mathrm{x}$ & $x$ & $x$ & $x$ & $x$ & $x$ & $x$ & $x$ \\
\hline Liberty International & & & & & & & & & $x$ & \\
\hline London Stock Exchange Group & & & & & & & & & & $\mathrm{x}$ \\
\hline Lonmin & & & & & & & & & & $x$ \\
\hline Marks \& Spencer & $x$ & $x$ & $x$ & $x$ & $x$ & $x$ & $x$ & $x$ & $x$ & \\
\hline Mitchells \& Butlers & & & & & & & $\mathrm{x}$ & & $\mathrm{x}$ & \\
\hline Pearson & $x$ & $\mathrm{x}$ & $x$ & $\mathrm{x}$ & $\mathrm{x}$ & $\mathrm{x}$ & $\mathrm{x}$ & $x$ & & \\
\hline Peninsular \& Oriental Steam Navigation & $x$ & $\mathrm{x}$ & $\mathrm{x}$ & $\mathrm{x}$ & $\mathrm{x}$ & $\mathrm{x}$ & & & & \\
\hline Pilkington & $x$ & $\mathrm{x}$ & $\mathrm{x}$ & $x$ & $\mathrm{x}$ & $x$ & & & & \\
\hline Prudential & & & & & & & & & & $\mathrm{x}$ \\
\hline Reed Elsevier & & & & & & & & & $x$ & $\mathrm{x}$ \\
\hline Rio Tinto & & & & & & & & & $\mathrm{x}$ & \\
\hline Royal Bank of Scotland & & & & & & & & & $x$ & \\
\hline Royal Dutch Shell & & & & & & & & $x$ & $\mathrm{x}$ & \\
\hline Sabmiller & $\mathrm{x}$ & $\mathrm{x}$ & $x$ & $x$ & $x$ & $\mathrm{x}$ & $\mathrm{x}$ & & & \\
\hline Scottish And Southern Energy & $\mathrm{x}$ & $x$ & $x$ & $x$ & $x$ & $\mathrm{x}$ & $x$ & $x$ & & \\
\hline Serco Group & & & & & & & & & $x$ & \\
\hline Severn Trent & $x$ & $x$ & $x$ & $x$ & $x$ & $x$ & $x$ & $x$ & & \\
\hline Slough Estates & $x$ & $\mathrm{x}$ & $x$ & $\mathrm{x}$ & $x$ & $x$ & $\mathrm{x}$ & & & \\
\hline Smith Nephew & $x$ & $x$ & $x$ & $x$ & $x$ & $x$ & $x$ & $x$ & $x$ & $x$ \\
\hline Smiths Group & & & & & & & $x$ & & & \\
\hline Taylor Woodrow & $x$ & $x$ & $x$ & $x$ & $x$ & $x$ & $x$ & & & \\
\hline The Capita Group & & & & & & & & & $x$ & $x$ \\
\hline Unilever & $x$ & $\mathrm{x}$ & $x$ & $x$ & $x$ & $x$ & $x$ & $x$ & $x$ & $x$ \\
\hline Vodafone Group & & & & & & & $\mathrm{x}$ & & & \\
\hline Whitbread & $x$ & $\mathrm{x}$ & $\mathrm{x}$ & $\mathrm{x}$ & $\mathrm{x}$ & $\mathrm{x}$ & $\mathrm{x}$ & $x$ & & $\mathrm{X}$ \\
\hline Yell Group & & & & & & & $x$ & $x$ & $\mathrm{x}$ & \\
\hline & & & & & & & & & & \\
\hline Total & 32 & 32 & 32 & 32 & 32 & 32 & 30 & 24 & 25 & 18 \\
\hline Number of companies that stayed on the list & & 32 & 32 & 32 & 32 & 32 & 23 & 16 & 16 & 11 \\
\hline Turnover $^{\mathrm{a}}$ & & 0 & 0 & 0 & 0 & 0 & 7 & 8 & 9 & 7 \\
\hline
\end{tabular}

Note: ${ }^{\text {a }}$ Annual average for the sample period $=3.44$, annual average for the period in which the Global 100 list is reported $=7.75$ (31 companies in total). 
Table 2a. Annual returns for single-year holding periods (1-year returns, February to January) and average annual geometric returns for multiple-year holding periods (5- and 10-year returns, February to January) and other sub-periods in years from 2000 to 2010 for the SRI portfolios (with dividends) and for the indexes FTSE100 (total return index) and FTSE4GOOD (total return index).

\begin{tabular}{|c|c|c|c|c|c|c|c|}
\hline $\begin{array}{l}\text { Single-year } \\
\text { Periods }\end{array}$ & $\begin{array}{l}\text { SRI Portfolio } \\
\text { with } \\
\text { dividends }\end{array}$ & $\begin{array}{l}\text { FTSE100 } \\
\text { total return } \\
\text { index }\end{array}$ & Difference & $t$-statistic & $\begin{array}{l}\text { FTSE4GOOD } \\
\text { total return } \\
\text { index }\end{array}$ & Difference & $t$-statistic \\
\hline 2000-01 & $24.22 \%$ & $2.67 \%$ & $21.55 \%$ & 1.14 & $2.55 \%$ & $21.67 \%$ & 1.20 \\
\hline $2001-02$ & $-2.45 \%$ & $-15.96 \%$ & $13.52 \%$ & 0.72 & $-14.73 \%$ & $12.28 \%$ & 0.66 \\
\hline 2002-03 & $-20.81 \%$ & $-28.81 \%$ & $7.99 \%$ & 0.33 & $-29.63 \%$ & $8.81 \%$ & 0.37 \\
\hline 2003-04 & $36.65 \%$ & $27.68 \%$ & $8.96 \%$ & 0.50 & $29.10 \%$ & $7.55 \%$ & 0.42 \\
\hline 2004-05 & $23.93 \%$ & $14.34 \%$ & $9.59 \%$ & 1.01 & $14.34 \%$ & $9.59 \%$ & 1.00 \\
\hline 2005-06 & $27.20 \%$ & $22.84 \%$ & $4.36 \%$ & 0.27 & $20.27 \%$ & $6.93 \%$ & 0.31 \\
\hline 2006-07 & $26.22 \%$ & $11.29 \%$ & $14.93 \%$ & 1.13 & $12.20 \%$ & $14.03 \%$ & 1.07 \\
\hline 2007-08 & $-10.99 \%$ & $-1.94 \%$ & $-9.06 \%$ & -0.55 & $-6.17 \%$ & $-4.83 \%$ & -0.32 \\
\hline 2008-09 & $-36.86 \%$ & $-26.33 \%$ & $-10.54 \%$ & -0.55 & $-26.31 \%$ & $-10.56 \%$ & -0.55 \\
\hline $2009-10$ & $30.56 \%$ & $30.40 \%$ & $0.16 \%$ & 0.02 & $30.60 \%$ & $-0.04 \%$ & 0.01 \\
\hline $\begin{array}{l}\text { Multiple- } \\
\text { year } \\
\text { Periods }\end{array}$ & $\begin{array}{l}\text { SRI Portfolio } \\
\text { with } \\
\text { dividends } \\
\end{array}$ & $\begin{array}{c}\text { FTSE100 } \\
\text { total return } \\
\text { index }\end{array}$ & Difference & $t$-statistic & $\begin{array}{l}\text { FTSE4GOOD } \\
\text { total return } \\
\text { index }\end{array}$ & Difference & $t$-statistic \\
\hline 2000-05 & $10.20 \%$ & $-2.16 \%$ & $12.35 \%$ & 1.32 * & $-1.90 \%$ & $12.10 \%$ & 1.30 * \\
\hline 2001-06 & $10.72 \%$ & $1.42 \%$ & $9.30 \%$ & 0.85 & $1.27 \%$ & $9.45 \%$ & 0.86 \\
\hline 2002-07 & $16.58 \%$ & $7.28 \%$ & $9.30 \%$ & 0.86 & $6.99 \%$ & $9.59 \%$ & 0.88 \\
\hline 2003-08 & $19.33 \%$ & $14.37 \%$ & $4.96 \%$ & 0.59 & $13.32 \%$ & $6.01 \%$ & 0.67 \\
\hline 2004-09 & $2.26 \%$ & $2.46 \%$ & $-0.20 \%$ & 0.13 & $1.30 \%$ & $0.95 \%$ & 0.22 \\
\hline $2005-10$ & $3.33 \%$ & $5.19 \%$ & $-1.86 \%$ & 0.00 & $4.03 \%$ & $-0.70 \%$ & 0.08 \\
\hline $\begin{array}{l}\text { Other Sub- } \\
\text { periods }\end{array}$ & $\begin{array}{l}\text { SRI Portfolio } \\
\text { with } \\
\text { dividends }\end{array}$ & $\begin{array}{l}\text { FTSE100 } \\
\text { total return } \\
\text { index }\end{array}$ & Difference & $t$-statistic & $\begin{array}{l}\text { FTSE4GOOD } \\
\text { total return } \\
\text { index }\end{array}$ & Difference & $t$-statistic \\
\hline $\begin{array}{l}\text { Growth } \\
\text { periods }\end{array}$ & $12.71 \%$ & $11.88 \%$ & $0.83 \%$ & 0.21 & $11.39 \%$ & $1.31 \%$ & 0.26 \\
\hline $\begin{array}{c}\text { Recession } \\
\text { periods }\end{array}$ & $3.18 \%$ & $-3.94 \%$ & $7.12 \%$ & 0.73 & $-4.33 \%$ & $7.52 \%$ & 0.77 \\
\hline Bull market & $26.27 \%$ & $20.95 \%$ & $5.32 \%$ & 0.67 & $20.56 \%$ & $5.71 \%$ & 0.71 \\
\hline $\begin{array}{c}\text { Bear } \\
\text { market }\end{array}$ & $-13.75 \%$ & $-18.40 \%$ & $4.65 \%$ & 0.43 & $-18.86 \%$ & $5.11 \%$ & 0.48 \\
\hline $\begin{array}{l}\text { Growth } \\
\text { periods }\end{array}$ & $\begin{array}{l}\text { SRI Portfolio } \\
\text { with } \\
\text { dividends }\end{array}$ & $\begin{array}{l}\text { FTSE100 } \\
\text { price index }\end{array}$ & Difference & $t$-statistic & $\begin{array}{l}\text { FTSE4GOOD } \\
\text { total return } \\
\text { index }\end{array}$ & Difference & $t$-statistic \\
\hline $2000-10$ & $6.71 \%$ & $1.45 \%$ & $5.26 \%$ & 0.75 & $1.02 \%$ & $5.69 \%$ & 0.80 \\
\hline
\end{tabular}

Notes: 1) * - significant at the $10 \%$ level. 2) The $t$-statistic was calculated based on the paired difference test. 3) Business cycles have been identified based on the methodology presented in Adam and Cobham (2009) and cover the following periods: Growth in 02.2000 09.2000, 7.2003 - 6.2004 and 10.2005 - 6.2007, Recession in 10.2000 - 6.2003, 7.2004 - 9.2005 and 7.2007 - 1.2010. 4) Bull and bear market periods have been identified using the idea of non-overlapping 'bull' and 'bear' phases based on major peaks and troughs found in the stock market indexes, presented in Gooding and O’Malley (1977) and more recently in Woodward and Anderson (2009), i.e. based on the variability of index FTSE100 in case of this study. Bull market periods cover: $4.2003-6.2007$ and 4.2009 - 1.2010 and bear market periods cover: $02.2000-3.2003$ and 7.2007 - 3.2009. 5) Periods of time for 'Other Sub-periods' are different in length than full calendar year, so returns in those rows are presented as annualised returns based on monthly returns. 6) Bold numbers indicate positive figures. 6) Cells highlighted grey identify the portfolio or index with the highest return for that period. 
Table 2b. Annual returns for single-year holding periods (1-year returns, February to January) and average annual geometric returns for multiple-year holding periods (5- and 10-year returns, February to January) and other sub-periods in years from 2000 to 2010 for the SRI portfolios (with dividends) and for the indexes FTSE100 (price index) and FTSE4GOOD (price index).

\begin{tabular}{|c|c|c|c|c|c|c|c|}
\hline $\begin{array}{l}\text { Single-year } \\
\text { Periods }\end{array}$ & $\begin{array}{l}\text { SRI Portfolio } \\
\text { with } \\
\text { dividends }\end{array}$ & $\begin{array}{l}\text { FTSE100 } \\
\text { price index }\end{array}$ & Difference & t-statistic & $\begin{array}{l}\text { FTSE4GOOD } \\
\text { price index }\end{array}$ & Difference & $t$-statistic \\
\hline 2000-01 & $24.22 \%$ & $0.46 \%$ & $23.76 \%$ & 1.28 & $0.36 \%$ & $23.86 \%$ & 1.34 * \\
\hline 2001-02 & $-2.45 \%$ & $-17.99 \%$ & $15.54 \%$ & 0.82 & $-16.55 \%$ & $14.11 \%$ & 0.76 \\
\hline 2002-03 & $-20.81 \%$ & $-30.93 \%$ & $10.11 \%$ & 0.43 & $-31.73 \%$ & $10.92 \%$ & 0.47 \\
\hline 2003-04 & $36.65 \%$ & $23.08 \%$ & $13.57 \%$ & 0.75 & $24.50 \%$ & $12.15 \%$ & 0.67 \\
\hline 2004-05 & $23.93 \%$ & $10.51 \%$ & $13.42 \%$ & 1.39 * & $10.55 \%$ & $13.38 \%$ & 1.36 * \\
\hline $2005-06$ & $27.20 \%$ & $18.71 \%$ & $8.49 \%$ & 0.34 & $16.23 \%$ & $10.97 \%$ & 0.39 \\
\hline 2006-07 & $26.22 \%$ & $7.69 \%$ & $18.53 \%$ & 1.40 * & $8.50 \%$ & $17.72 \%$ & 1.35 * \\
\hline 2007-08 & $-10.99 \%$ & $-5.21 \%$ & $-5.78 \%$ & -0.37 & $-9.36 \%$ & $-1.63 \%$ & -0.13 \\
\hline 2008-09 & $-36.86 \%$ & $-29.43 \%$ & $-7.44 \%$ & -0.41 & $-29.60 \%$ & $-7.26 \%$ & -0.40 \\
\hline $2009-10$ & $30.56 \%$ & $25.04 \%$ & $5.52 \%$ & 0.19 & $25.02 \%$ & $5.54 \%$ & 0.18 \\
\hline $\begin{array}{l}\text { Multiple- } \\
\text { year } \\
\text { Periods }\end{array}$ & $\begin{array}{l}\text { SRI Portfolio } \\
\text { with } \\
\text { dividends }\end{array}$ & $\begin{array}{l}\text { FTSE100 } \\
\text { price index }\end{array}$ & Difference & $t$-statistic & $\begin{array}{l}\text { FTSE4GOOD } \\
\text { price index }\end{array}$ & Difference & $t$-statistic \\
\hline $2000-05$ & $10.20 \%$ & $-4.99 \%$ & $15.19 \%$ & 1.65 * & $-4.68 \%$ & $14.88 \%$ & 1.62 * \\
\hline 2001-06 & $10.72 \%$ & $-1.77 \%$ & $12.49 \%$ & 1.10 & $-1.84 \%$ & $12.56 \%$ & 1.11 \\
\hline $2002-07$ & $16.58 \%$ & $3.73 \%$ & $12.84 \%$ & 1.14 & $3.45 \%$ & $13.12 \%$ & 1.17 \\
\hline 2003-08 & $19.33 \%$ & $10.51 \%$ & $8.82 \%$ & 0.91 & $9.49 \%$ & $9.85 \%$ & 0.99 \\
\hline 2004-09 & $2.26 \%$ & $-1.12 \%$ & $3.38 \%$ & 0.42 & $-2.31 \%$ & $4.57 \%$ & 0.52 \\
\hline 2005-10 & $3.33 \%$ & $1.35 \%$ & $1.98 \%$ & 0.28 & $0.12 \%$ & $3.21 \%$ & 0.37 \\
\hline $\begin{array}{l}\text { Other Sub- } \\
\text { periods }\end{array}$ & $\begin{array}{l}\text { SRI Portfolio } \\
\text { with } \\
\text { dividends }\end{array}$ & $\begin{array}{l}\text { FTSE100 } \\
\text { price index }\end{array}$ & Difference & $t$-statistic & $\begin{array}{l}\text { FTSE4GOOD } \\
\text { price index }\end{array}$ & Difference & $t$-statistic \\
\hline $\begin{array}{l}\text { Growth } \\
\text { periods }\end{array}$ & $12.71 \%$ & $8.63 \%$ & $4.08 \%$ & 0.51 & $8.23 \%$ & $4.47 \%$ & 0.55 \\
\hline $\begin{array}{l}\text { Recession } \\
\text { periods }\end{array}$ & $3.18 \%$ & $-7.31 \%$ & $10.49 \%$ & 1.05 & $-7.78 \%$ & $10.96 \%$ & 1.10 \\
\hline Bull market & $26.27 \%$ & $17.49 \%$ & $8.78 \%$ & 1.00 & $17.04 \%$ & $9.23 \%$ & 1.04 \\
\hline $\begin{array}{c}\text { Bear } \\
\text { market }\end{array}$ & $-13.75 \%$ & $-21.60 \%$ & $7.85 \%$ & 0.73 & $-22.04 \%$ & $8.29 \%$ & 0.78 \\
\hline Full Period & $\begin{array}{l}\text { SRI Portfolio } \\
\text { with } \\
\text { dividends }\end{array}$ & $\begin{array}{l}\text { FTSE100 } \\
\text { price index }\end{array}$ & Difference & t-statistic & $\begin{array}{l}\text { FTSE4GOOD } \\
\text { price index }\end{array}$ & Difference & $t$-statistic \\
\hline $2000-10$ & $6.71 \%$ & $-1.87 \%$ & $8.58 \%$ & 1.16 & $-2.31 \%$ & $9.02 \%$ & 1.22 \\
\hline
\end{tabular}

Notes: 1) * - significant at the $10 \%$ level. 2) The $t$-statistic was calculated based on the paired difference test. 3) Business cycles have been identified based on the methodology presented in Adam and Cobham (2009) and cover the following periods: Growth in $02.2000-$ 09.2000, 7.2003 - 6.2004 and 10.2005 - 6.2007, Recession in 10.2000 - 6.2003, 7.2004 - 9.2005 and 7.2007 - 1.2010. 4) Bull and bear market periods have been identified using the idea of non-overlapping 'bull' and 'bear' phases based on major peaks and troughs found in the stock market indexes, presented in Gooding and O’Malley (1977) and more recently in Woodward and Anderson (2009), i.e. based on the variability of index FTSE100 in case of this study. Bull market periods cover: $4.2003-6.2007$ and $4.2009-1.2010$ and bear market periods cover: 02.2000 - 3.2003 and 7.2007 - 3.2009. 5) Periods of time for 'Other Sub-periods' are different in length than full calendar year, so returns in those rows are presented as annualised returns based on monthly returns. 6) Bold numbers indicate positive figures. 6) Cells highlighted grey identify the portfolio or index with the highest return for that period. 
Table 2c. Annual returns for single-year holding periods (1-year returns, February to January) and average annual geometric returns for multiple-year holding periods (5- and 10-year returns, February to January) and other sub-periods in years from 2000 to 2010 for the SRI portfolios (without dividends) and for the indexes FTSE100 (price index) and FTSE4GOOD (price index).

\begin{tabular}{|c|c|c|c|c|c|c|c|}
\hline $\begin{array}{l}\text { Single-year } \\
\text { Periods }\end{array}$ & $\begin{array}{l}\text { SRI Portfolio } \\
\text { without } \\
\text { dividends }\end{array}$ & $\begin{array}{l}\text { FTSE100 } \\
\text { price index }\end{array}$ & Difference & $t$-statistic & $\begin{array}{l}\text { FTSE4GOOD } \\
\text { price index }\end{array}$ & Difference & t-statistic \\
\hline 2000-01 & $20.17 \%$ & $0.46 \%$ & $19.71 \%$ & 1.07 & $0.36 \%$ & $19.81 \%$ & 1.12 \\
\hline 2001-02 & $-5.70 \%$ & $-17.99 \%$ & $12.29 \%$ & 0.67 & $-16.55 \%$ & $10.86 \%$ & 0.60 \\
\hline 2002-03 & $-23.97 \%$ & $-30.93 \%$ & $6.96 \%$ & 0.31 & $-31.73 \%$ & $7.76 \%$ & 0.35 \\
\hline 2003-04 & $32.13 \%$ & $23.08 \%$ & $9.06 \%$ & 0.49 & $24.50 \%$ & $7.63 \%$ & 0.41 \\
\hline 2004-05 & $19.68 \%$ & $10.51 \%$ & $9.17 \%$ & 0.93 & $10.55 \%$ & $9.13 \%$ & 0.91 \\
\hline 2005-06 & $22.99 \%$ & $18.71 \%$ & $4.28 \%$ & 0.28 & $16.23 \%$ & $6.77 \%$ & 0.32 \\
\hline 2006-07 & $20.77 \%$ & $7.69 \%$ & $13.09 \%$ & 1.00 & $8.50 \%$ & $12.27 \%$ & 0.94 \\
\hline 2007-08 & $-15.29 \%$ & $-5.21 \%$ & $-10.08 \%$ & -0.61 & $-9.36 \%$ & $-5.93 \%$ & -0.36 \\
\hline 2008-09 & $-40.73 \%$ & $-29.43 \%$ & $-11.30 \%$ & -0.57 & $-29.60 \%$ & $-11.13 \%$ & -0.57 \\
\hline 2009-10 & $26.68 \%$ & $25.04 \%$ & $1.64 \%$ & 0.05 & $25.02 \%$ & $1.66 \%$ & 0.05 \\
\hline $\begin{array}{l}\text { Multiple-year } \\
\text { Periods }\end{array}$ & $\begin{array}{l}\text { SRI Portfolio } \\
\text { without } \\
\text { dividends }\end{array}$ & $\begin{array}{l}\text { FTSE100 } \\
\text { price index }\end{array}$ & Difference & $t$-statistic & $\begin{array}{l}\text { FTSE4GOOD } \\
\text { price index }\end{array}$ & Difference & t-statistic \\
\hline 2000-05 & $6.38 \%$ & $-4.99 \%$ & $11.38 \%$ & 1.25 & $-4.68 \%$ & $11.06 \%$ & 1.22 \\
\hline 2001-06 & $6.88 \%$ & $-1.77 \%$ & $8.65 \%$ & 0.82 & $-1.84 \%$ & $8.72 \%$ & 0.83 \\
\hline 2002-07 & $12.30 \%$ & $3.73 \%$ & $8.57 \%$ & 0.82 & $3.45 \%$ & $8.85 \%$ & 0.84 \\
\hline 2003-08 & $14.75 \%$ & $10.51 \%$ & $4.24 \%$ & 0.53 & $9.49 \%$ & $5.27 \%$ & 0.62 \\
\hline 2004-09 & $-2.25 \%$ & $-1.12 \%$ & $-1.12 \%$ & 0.08 & $-2.31 \%$ & $0.07 \%$ & 0.18 \\
\hline 2005-10 & $-1.13 \%$ & $1.35 \%$ & $-2.48 \%$ & -0.03 & $0.12 \%$ & $-1.25 \%$ & 0.06 \\
\hline
\end{tabular}

\begin{tabular}{|c|c|c|c|c|c|c|c|}
\hline $\begin{array}{c}\text { Other Sub- } \\
\text { periods }\end{array}$ & $\begin{array}{c}\text { SRI Portfolio } \\
\text { without } \\
\text { dividends }\end{array}$ & $\begin{array}{c}\text { FTSE100 } \\
\text { price index }\end{array}$ & Difference & t-statistic & $\begin{array}{c}\text { FTSE4GOOD } \\
\text { price index }\end{array}$ & Difference & $t$-statistic \\
\hline $\begin{array}{c}\text { Growth } \\
\text { periods }\end{array}$ & $\mathbf{8 . 7 7 \%}$ & $\mathbf{8 . 6 3 \%}$ & $\mathbf{0 . 1 5 \%}$ & $\mathbf{0 . 1 5}$ & $\mathbf{8 . 2 3 \%}$ & $\mathbf{0 . 5 4 \%}$ & $\mathbf{0 . 1 9}$ \\
\hline $\begin{array}{c}\text { Recession } \\
\text { periods }\end{array}$ & $-0.70 \%$ & $-7.31 \%$ & $\mathbf{6 . 6 1 \%}$ & $\mathbf{0 . 6 9}$ & $-7.78 \%$ & $\mathbf{7 . 0 8 \%}$ & $\mathbf{0 . 7 3}$ \\
\hline Bull market & $\mathbf{2 2 . 2 4 \%}$ & $\mathbf{1 7 . 4 9 \%}$ & $\mathbf{4 . 7 5 \%}$ & $\mathbf{0 . 6 2}$ & $\mathbf{1 7 . 0 4 \%}$ & $\mathbf{5 . 2 0 \%}$ & $\mathbf{0 . 6 6}$ \\
\hline Bear market & $-17.52 \%$ & $-21.60 \%$ & $\mathbf{4 . 0 8} \%$ & $\mathbf{0 . 3 8}$ & $-22.04 \%$ & $\mathbf{4 . 5 3 \%}$ & $\mathbf{0 . 4 3}$ \\
\hline Full Period & $\begin{array}{c}\text { SRI Portfolio } \\
\text { with } \\
\text { dividends }\end{array}$ & $\begin{array}{c}\text { FTSE100 } \\
\text { price index }\end{array}$ & Difference & $t$-statistic & $\begin{array}{c}\text { FTSE4GOOD } \\
\text { price index }\end{array}$ & Difference & $t$-statistic \\
\hline $2000-10$ & $\mathbf{2 . 5 6 \%}$ & $-1.87 \%$ & $\mathbf{4 . 4 3 \%}$ & $\mathbf{0 . 6 8}$ & $-2.31 \%$ & $\mathbf{4 . 8 7 \%}$ & $\mathbf{0 . 7 4}$ \\
\hline
\end{tabular}

Notes: 1) * - significant at the $10 \%$ level. 2) The $t$-statistic was calculated based on the paired difference test. 3) Business cycles have been identified based on the methodology presented in Adam and Cobham (2009) and cover the following periods: Growth in 02.2000 09.2000, 7.2003 - 6.2004 and 10.2005 - 6.2007, Recession in 10.2000 - 6.2003, 7.2004 - 9.2005 and 7.2007 - 1.2010. 4) Bull and bear market periods have been identified using the idea of non-overlapping 'bull' and 'bear' phases based on major peaks and troughs found in the stock market indexes, presented in Gooding and O'Malley (1977) and more recently in Woodward and Anderson (2009), i.e. based on the variability of index FTSE100 in case of this study. Bull market periods cover: $4.2003-6.2007$ and 4.2009 - 1.2010 and bear market periods cover: 02.2000 - 3.2003 and 7.2007 - 3.2009. 5) Periods of time for 'Other Sub-periods' are different in length than full calendar year, so returns in those rows are presented as annualised returns based on monthly returns. 6) Bold numbers indicate positive figures. 6) Cells highlighted grey identify the portfolio or index with the highest return for that period. 
Table 3. Modified Sharpe ratios (MSR) and standard deviations (SD) for the SRI portfolios (with dividends) and for the indexes FTSE100 (total return index) and FTSE4GOOD (total return index) in years from 2000 to 2010.

\begin{tabular}{|c|c|c|c|c|c|c|}
\hline & \multicolumn{2}{|c|}{$\begin{array}{l}\text { SRI Portfolio } \\
\text { with dividends }\end{array}$} & \multicolumn{2}{|c|}{$\begin{array}{c}\text { FTSE100 } \\
\text { total return index }\end{array}$} & \multicolumn{2}{|c|}{$\begin{array}{l}\text { FTSE4GOOD } \\
\text { total return index }\end{array}$} \\
\hline $\begin{array}{l}\text { Single-year } \\
\text { Periods }\end{array}$ & $M S R$ & $S D$ & $M S R$ & $S D$ & $M S R$ & $S D$ \\
\hline 2000-01 & 0.3944 & $3.64 \%$ & -0.0001 & $3.39 \%$ & -0.0001 & $3.07 \%$ \\
\hline 2001-02 & -0.0002 & $4.56 \%$ & -0.0007 & $4.04 \%$ & -0.0006 & $3.91 \%$ \\
\hline 2002-03 & -0.0012 & $5.47 \%$ & -0.0018 & $6.23 \%$ & -0.0019 & $6.22 \%$ \\
\hline 2003-04 & 0.8189 & $2.96 \%$ & 0.5892 & $3.06 \%$ & 0.6129 & $3.10 \%$ \\
\hline 2004-05 & 0.7865 & $1.88 \%$ & 0.4923 & $1.55 \%$ & 0.4734 & $1.62 \%$ \\
\hline $2005-06$ & 0.1824 & $13.28 \%$ & 0.5991 & $2.31 \%$ & 0.5394 & $2.23 \%$ \\
\hline $2006-07$ & 0.6318 & $2.61 \%$ & 0.2394 & $2.21 \%$ & 0.2746 & $2.18 \%$ \\
\hline 2007-08 & -0.0005 & $3.71 \%$ & -0.0002 & $3.78 \%$ & -0.0003 & $3.76 \%$ \\
\hline 2008-09 & -0.0024 & $5.97 \%$ & -0.0016 & $6.05 \%$ & -0.0016 & $6.03 \%$ \\
\hline \multirow[t]{2}{*}{$2009-10$} & 0.4740 & $4.96 \%$ & 0.4476 & $5.18 \%$ & 0.4418 & $5.29 \%$ \\
\hline & \multicolumn{2}{|c|}{$\begin{array}{c}\text { SRI Portfolio } \\
\text { with dividends }\end{array}$} & \multicolumn{2}{|c|}{$\begin{array}{c}\text { FTSE100 } \\
\text { total return index }\end{array}$} & \multicolumn{2}{|c|}{$\begin{array}{c}\text { FTSE4GOOD } \\
\text { total return index }\end{array}$} \\
\hline $\begin{array}{l}\text { Multiple-year } \\
\text { Periods }\end{array}$ & $M S R$ & $S D$ & $M S R$ & $S D$ & $M S R$ & $S D$ \\
\hline $2000-05$ & 0.1316 & $4.12 \%$ & -0.0002 & $4.19 \%$ & -0.0002 & $4.14 \%$ \\
\hline 2001-06 & 0.1068 & $6.92 \%$ & -0.0001 & $4.12 \%$ & -0.0001 & $4.10 \%$ \\
\hline $2002-07$ & 0.1736 & $6.70 \%$ & 0.0824 & $3.77 \%$ & 0.0763 & $3.78 \%$ \\
\hline 2003-08 & 0.2054 & $6.40 \%$ & 0.2891 & $2.73 \%$ & 0.2580 & $2.76 \%$ \\
\hline 2004-09 & 0.0041 & $7.06 \%$ & 0.0000 & $3.73 \%$ & -0.0001 & $3.71 \%$ \\
\hline $2005-10$ & 0.0276 & $7.38 \%$ & 0.0468 & $4.40 \%$ & 0.0258 & $4.42 \%$ \\
\hline $\begin{array}{c}\text { Other } \\
\text { Sub-periods }\end{array}$ & MSR & $S D$ & $M S R$ & $S D$ & $M S R$ & $S D$ \\
\hline Growth periods & 0.1546 & $5.34 \%$ & 0.2511 & $2.51 \%$ & 0.2434 & $2.41 \%$ \\
\hline Recession periods & 0.0220 & $6.26 \%$ & -0.0003 & $4.94 \%$ & -0.0003 & $4.94 \%$ \\
\hline Bull market & 0.3257 & $6.36 \%$ & 0.5128 & $2.87 \%$ & 0.4931 & $2.92 \%$ \\
\hline Bear market & -0.0007 & $4.96 \%$ & -0.0009 & $4.88 \%$ & -0.0009 & $4.81 \%$ \\
\hline Full Period & MSR & $S D$ & $M S R$ & $S D$ & MSR & $S D$ \\
\hline $2000-10$ & 0.0627 & $5.95 \%$ & -0.0001 & $4.29 \%$ & -0.0001 & $4.27 \%$ \\
\hline
\end{tabular}

Notes: 1) The modified Sharpe ratio was calculated based on the formula from Israelsen (2005): $M S R=E R / S D^{(E R / a b s E R)}$, where $E R$ is the excess return defined as mean monthly difference between the portfolio (or index) return and the riskfree return computed for $n$ equal to 12, 60 or 120 months, respectfully, and $S D$ is the sample standard deviation of the monthly differences of returns. The risk-free rate for the United Kingdom market used was the return on the UK Treasury Bill obtained from Xfi Centre for Finance and Investment (see Gregory et al., 2009 and 2011). 2) Business cycles have been identified based on the methodology presented in Adam and Cobham (2009) and cover the following periods: Growth in 02.2000 - 09.2000, $7.2003-6.2004$ and $10.2005-6.2007$, Recession in $10.2000-6.2003,7.2004$ - 9.2005 and $7.2007-1.2010$. 3) Bull and bear market periods have been identified using the idea of non-overlapping 'bull' and 'bear' phases based on major peaks and troughs found in the stock market indexes, presented in Gooding and O’Malley (1977) and more recently in Woodward and Anderson (2009), i.e. based on the index FTSE100 in case of this study. Bull market periods cover: $4.2003-6.2007$ and 4.2009 - 1.2010 and bear market periods cover: 02.2000 3.2003 and 7.2007 - 3.2009. 4) Bold numbers indicate positive MSR figures. 5) Cells highlighted grey identify the portfolio or index with the highest $M S R$ ratio for that period. 
Table 4. Certainty Equivalent (CEQ) returns (for risk aversion parameters: $\gamma=0.5, \gamma=1$ and $\gamma=2$ ) for the SRI portfolios (with dividends) and for the indexes FTSE100 (total return index) and FTSE4GOOD (total return index) in years from 2000 to 2010.

\begin{tabular}{|c|c|c|c|c|c|c|c|c|c|}
\hline $\begin{array}{c}C E Q \\
\gamma \text { parameter: }\end{array}$ & \multicolumn{3}{|c|}{$\gamma=0.5$} & \multicolumn{3}{|c|}{$\gamma=1$} & \multicolumn{3}{|c|}{$\gamma=2$} \\
\hline $\begin{array}{l}\text { Single-year } \\
\text { Periods }\end{array}$ & $\begin{array}{c}\text { SRI } \\
\text { Portfolio } \\
\text { with } \\
\text { dividends }\end{array}$ & $\begin{array}{l}\text { FTSE100 } \\
\text { total return } \\
\text { index }\end{array}$ & $\begin{array}{l}\text { FTSE4GOOD } \\
\text { total return } \\
\text { index }\end{array}$ & $\begin{array}{c}\text { SRI } \\
\text { Portfolio } \\
\text { with } \\
\text { dividends }\end{array}$ & $\begin{array}{l}\text { FTSE100 } \\
\text { total return } \\
\text { index }\end{array}$ & $\begin{array}{l}\text { FTSE4GOOD } \\
\text { total return } \\
\text { index }\end{array}$ & $\begin{array}{c}\text { SRI } \\
\text { Portfolio } \\
\text { with } \\
\text { dividends }\end{array}$ & $\begin{array}{l}\text { FTSE100 } \\
\text { total return } \\
\text { index }\end{array}$ & $\begin{array}{l}\text { FTSE4GOOD } \\
\text { total return } \\
\text { index }\end{array}$ \\
\hline 2000-01 & $1.40 \%$ & $-0.23 \%$ & $-0.24 \%$ & $1.37 \%$ & $-0.25 \%$ & $-0.26 \%$ & $1.30 \%$ & $-0.31 \%$ & $-0.31 \%$ \\
\hline 2001-02 & $-0.53 \%$ & $-1.77 \%$ & $-1.66 \%$ & $-0.58 \%$ & $-1.81 \%$ & $-1.69 \%$ & $-0.68 \%$ & $-1.90 \%$ & $-1.77 \%$ \\
\hline 2002-03 & $-2.22 \%$ & $-3.03 \%$ & $-3.12 \%$ & $-2.30 \%$ & $-3.12 \%$ & $-3.22 \%$ & $-2.45 \%$ & $-3.32 \%$ & $-3.41 \%$ \\
\hline 2003-04 & $2.40 \%$ & $1.78 \%$ & $1.88 \%$ & $2.38 \%$ & $1.76 \%$ & $1.85 \%$ & $2.33 \%$ & $1.71 \%$ & $1.80 \%$ \\
\hline 2004-05 & $1.47 \%$ & $0.76 \%$ & $0.76 \%$ & $1.46 \%$ & $0.75 \%$ & $0.75 \%$ & $1.44 \%$ & $0.74 \%$ & $0.74 \%$ \\
\hline 2005-06 & $1.98 \%$ & $1.37 \%$ & $1.19 \%$ & $1.54 \%$ & $1.36 \%$ & $1.18 \%$ & $0.66 \%$ & $1.33 \%$ & $1.15 \%$ \\
\hline 2006-07 & $1.63 \%$ & $0.52 \%$ & $0.59 \%$ & $1.61 \%$ & $0.51 \%$ & $0.57 \%$ & $1.58 \%$ & $0.48 \%$ & $0.55 \%$ \\
\hline 2007-08 & $-1.43 \%$ & $-0.58 \%$ & $-0.94 \%$ & $-1.46 \%$ & $-0.61 \%$ & $-0.98 \%$ & $-1.53 \%$ & $-0.69 \%$ & $-1.05 \%$ \\
\hline 2008-09 & $-4.10 \%$ & $-2.75 \%$ & $-2.75 \%$ & $-4.19 \%$ & $-2.84 \%$ & $-2.84 \%$ & $-4.37 \%$ & $-3.02 \%$ & $-3.02 \%$ \\
\hline 2009-10 & $2.29 \%$ & $2.25 \%$ & $2.27 \%$ & $2.23 \%$ & $2.18 \%$ & $2.20 \%$ & $2.11 \%$ & $2.05 \%$ & $2.06 \%$ \\
\hline $\begin{array}{c}\text { Multiple-year } \\
\text { Periods }\end{array}$ & $\begin{array}{c}\text { SRI } \\
\text { Portfolio } \\
\text { with } \\
\text { dividends }\end{array}$ & $\begin{array}{l}\text { FTSE100 } \\
\text { total return } \\
\text { index }\end{array}$ & $\begin{array}{l}\text { FTSE4GOOD } \\
\text { total return } \\
\text { index }\end{array}$ & $\begin{array}{c}\text { SRI } \\
\text { Portfolio } \\
\text { with } \\
\text { dividends }\end{array}$ & $\begin{array}{l}\text { FTSE100 } \\
\text { total return } \\
\text { index }\end{array}$ & $\begin{array}{l}\text { FTSE4GOOD } \\
\text { total return } \\
\text { index }\end{array}$ & $\begin{array}{c}\text { SRI } \\
\text { Portfolio } \\
\text { with } \\
\text { dividends }\end{array}$ & $\begin{array}{l}\text { FTSE100 } \\
\text { total return } \\
\text { index }\end{array}$ & $\begin{array}{l}\text { FTSE4GOOD } \\
\text { total return } \\
\text { index }\end{array}$ \\
\hline 2000-05 & $0.50 \%$ & $-0.50 \%$ & $-0.48 \%$ & $0.46 \%$ & $-0.55 \%$ & $-0.52 \%$ & $0.37 \%$ & $-0.63 \%$ & $-0.61 \%$ \\
\hline 2001-06 & $0.62 \%$ & $-0.18 \%$ & $-0.20 \%$ & $0.50 \%$ & $-0.23 \%$ & $-0.24 \%$ & $0.26 \%$ & $-0.31 \%$ & $-0.32 \%$ \\
\hline $2002-07$ & $1.05 \%$ & $0.28 \%$ & $0.25 \%$ & $0.94 \%$ & $0.24 \%$ & $0.22 \%$ & $0.71 \%$ & $0.17 \%$ & $0.15 \%$ \\
\hline 2003-08 & $1.21 \%$ & $0.77 \%$ & $0.69 \%$ & $1.11 \%$ & $0.75 \%$ & $0.67 \%$ & $0.91 \%$ & $0.71 \%$ & $0.64 \%$ \\
\hline 2004-09 & $-0.10 \%$ & $-0.14 \%$ & $-0.23 \%$ & $-0.22 \%$ & $-0.17 \%$ & $-0.27 \%$ & $-0.47 \%$ & $-0.24 \%$ & $-0.34 \%$ \\
\hline $2005-10$ & $0.07 \%$ & $0.16 \%$ & $0.07 \%$ & $-0.07 \%$ & $0.11 \%$ & $0.02 \%$ & $-0.34 \%$ & $0.01 \%$ & $-0.08 \%$ \\
\hline
\end{tabular}


Table 4. (continued)

\begin{tabular}{|c|c|c|c|c|c|c|c|c|c|}
\hline $\begin{array}{c}C E Q \\
\gamma \text { parameter: }\end{array}$ & \multicolumn{3}{|c|}{$\gamma=0.5$} & \multicolumn{3}{|c|}{$\gamma=1$} & \multicolumn{3}{|c|}{$\gamma=2$} \\
\hline $\begin{array}{c}\text { Other } \\
\text { Sub-periods }\end{array}$ & $\begin{array}{c}\text { SRI } \\
\text { Portfolio } \\
\text { with } \\
\text { dividends }\end{array}$ & $\begin{array}{l}\text { FTSE100 } \\
\text { total return } \\
\text { index }\end{array}$ & $\begin{array}{l}\text { FTSE4GOOD } \\
\text { total return } \\
\text { index }\end{array}$ & $\begin{array}{c}\text { SRI } \\
\text { Portfolio } \\
\text { with } \\
\text { dividends }\end{array}$ & $\begin{array}{l}\text { FTSE100 } \\
\text { total return } \\
\text { index }\end{array}$ & $\begin{array}{l}\text { FTSE4GOOD } \\
\text { total return } \\
\text { index }\end{array}$ & $\begin{array}{c}\text { SRI } \\
\text { Portfolio } \\
\text { with } \\
\text { dividends }\end{array}$ & $\begin{array}{l}\text { FTSE100 } \\
\text { total return } \\
\text { index }\end{array}$ & $\begin{array}{l}\text { FTSE4GOOD } \\
\text { total return } \\
\text { index }\end{array}$ \\
\hline Growth periods & $0.75 \%$ & $0.61 \%$ & $0.57 \%$ & $0.68 \%$ & $0.60 \%$ & $0.56 \%$ & $0.54 \%$ & $0.57 \%$ & $0.53 \%$ \\
\hline $\begin{array}{l}\text { Recession } \\
\text { periods }\end{array}$ & $0.04 \%$ & $-0.58 \%$ & $-0.61 \%$ & $-0.06 \%$ & $-0.64 \%$ & $-0.67 \%$ & $-0.25 \%$ & $-0.76 \%$ & $-0.80 \%$ \\
\hline Bull market & $1.97 \%$ & $1.45 \%$ & $1.42 \%$ & $1.87 \%$ & $1.43 \%$ & $1.40 \%$ & $1.67 \%$ & $1.39 \%$ & $1.35 \%$ \\
\hline Bear market & $-1.45 \%$ & $-1.84 \%$ & $-1.88 \%$ & $-1.51 \%$ & $-1.90 \%$ & $-1.93 \%$ & $-1.63 \%$ & $-2.02 \%$ & $-2.05 \%$ \\
\hline Full Period & $\begin{array}{c}\text { SRI } \\
\text { Portfolio } \\
\text { with } \\
\text { dividends }\end{array}$ & $\begin{array}{l}\text { FTSE100 } \\
\text { price index }\end{array}$ & $\begin{array}{l}\text { FTSE4GOOD } \\
\text { price index }\end{array}$ & $\begin{array}{c}\text { SRI } \\
\text { Portfolio } \\
\text { with } \\
\text { dividends }\end{array}$ & $\begin{array}{l}\text { FTSE100 } \\
\text { price index }\end{array}$ & $\begin{array}{l}\text { FTSE4GOOD } \\
\text { price index }\end{array}$ & $\begin{array}{c}\text { SRI } \\
\text { Portfolio } \\
\text { with } \\
\text { dividends }\end{array}$ & $\begin{array}{l}\text { FTSE100 } \\
\text { price index }\end{array}$ & $\begin{array}{l}\text { FTSE4GOOD } \\
\text { price index }\end{array}$ \\
\hline $2000-10$ & $0.28 \%$ & $-0.17 \%$ & $-0.21 \%$ & $0.20 \%$ & $-0.22 \%$ & $-0.25 \%$ & $0.02 \%$ & $-0.31 \%$ & $-0.34 \%$ \\
\hline
\end{tabular}

Notes: 1) Certainty Equivalent (CEQ) returns are defined as: $\hat{\mu}_{k}-(\gamma / 2) \hat{\sigma}_{k}^{2}$, where $\hat{\mu}_{k}$ and $\hat{\sigma}_{k}^{2}$ are the mean and variance of excess returns of a portfolio or an index $k$ and $\gamma$ is the risk aversion parameter. The risk-free rate for the United Kingdom market used was the return on the UK Treasury Bill obtained from Xfi Centre for Finance and Investment (see Gregory et al., 2009 and 2011). This formulation of CEQ assumes a multi-period investor with quadratic utility. The 'normal' level of risk aversion is 1, while higher (lower) values indicate higher (lower) levels of risk aversion. 2) Business cycles have been identified based on the methodology presented in Adam and Cobham (2009) and cover the following periods: Growth in 02.2000 - 09.2000, 7.2003 - 6.2004 and 10.2005 - 6.2007, Recession in 10.2000 - 6.2003, 7.2004 - 9.2005 and 7.2007 - 1.2010. 3) Bull and bear market periods have been identified using the idea of non-overlapping 'bull' and 'bear' phases based on major peaks and troughs found in the stock market indexes, presented in Gooding and O'Malley (1977) and more recently in Woodward and Anderson (2009), i.e. based on the index FTSE100 in case of this study. Bull market periods cover: 4.2003 - 6.2007 and 4.2009 - 1.2010 and bear market periods cover: 02.2000 - 3.2003 and 7.2007 - 3.2009. 4) Bold numbers indicate positive CEQ figures. 5) Cells highlighted grey identify the portfolio or index with the highest $C E Q$ value for that period and for a given risk aversion level of $\gamma$. 
Table 5. Total returns of investment in SRI portfolios (with and without dividends) and total returns of the benchmark buy-and-hold strategy for the indexes FTSE100 (price index), FTSE100 (total return index), FTSE4GOOD (price index) and FTSE4GOOD (total return index) in the period from 2000 to 2010 calculated with different levels of trading costs.

\begin{tabular}{|c|c|c|c|c|c|c|}
\hline \multicolumn{7}{|c|}{ SRI portfolios strategy total returns: } \\
\hline Transaction Costs: & $0.00 \%$ & $0.50 \%$ & $1.00 \%$ & $2.00 \%$ & $3.00 \%$ & $4.00 \%$ \\
\hline $\begin{array}{l}\text { SRI Portfolio } \\
\text { (with dividends) }\end{array}$ & $91.42 \%$ & $82.08 \%$ & $73.16 \%$ & $56.57 \%$ & $41.49 \%$ & $27.80 \%$ \\
\hline $\begin{array}{c}\text { SRI Portfolio } \\
\text { (without dividends) }\end{array}$ & $28.73 \%$ & $22.45 \%$ & $16.45 \%$ & $5.29 \%$ & $-4.85 \%$ & $-14.06 \%$ \\
\hline \multicolumn{7}{|c|}{ Benchmark index total returns (buy-and-hold strategy): } \\
\hline Transaction Costs: & $0.00 \%$ & $0.50 \%$ & $1.00 \%$ & $2.00 \%$ & $3.00 \%$ & $4.00 \%$ \\
\hline $\begin{array}{l}\text { FTSE100 } \\
\text { total return index }\end{array}$ & $15.49 \%$ & $14.95 \%$ & $14.41 \%$ & $13.33 \%$ & $12.26 \%$ & $11.18 \%$ \\
\hline $\begin{array}{l}\text { FTSE4GOOD } \\
\text { total return index }\end{array}$ & $10.70 \%$ & $10.17 \%$ & $9.64 \%$ & $8.59 \%$ & $7.54 \%$ & $6.48 \%$ \\
\hline $\begin{array}{l}\text { FTSE100 } \\
\text { price index }\end{array}$ & $-17.23 \%$ & $-17.69 \%$ & $-18.14 \%$ & $-19.06 \%$ & $-19.97 \%$ & $-20.88 \%$ \\
\hline $\begin{array}{l}\text { FTSE4GOOD } \\
\text { price index }\end{array}$ & $-20.84 \%$ & $-21.29 \%$ & $-21.74 \%$ & $-22.63 \%$ & $-23.53 \%$ & $-24.42 \%$ \\
\hline
\end{tabular}

Note: The above calculations assume that transaction costs are for the round-trip trades, i.e. they already cover the cost of buying and selling stocks (or indexes) at the beginning and at the end of the respective period. The SRI portfolios are re-balanced every year, so the transaction costs are assumed to be incurred by investors in all 10 annual sub-periods, while for the buy-and-hold strategies for the stock market indexes the transaction costs are assumed to be incurred only at the beginning and then at the end of the entire 10 year period. 
Table 6. Estimation results of parameters of Fama-French three-factor model in single and multiple-year periods (in years from 2000 to 2010).

\begin{tabular}{|c|c|c|c|c|c|}
\hline & constant & $R M R F_{t}$ & $S M B_{t}$ & $H M L_{t}$ & $R$-squared \\
\hline \multicolumn{6}{|c|}{ Single-year Periods } \\
\hline $2000-01$ & 0.0048 & 0.7813 ** & 0.1788 & 0.3650 ** & 0.66 \\
\hline 2001-02 & 0.0063 & 0.2413 & 0.5598 *** & -0.4751 & 0.88 \\
\hline $2002-03$ & 0.0131 ** & $0.9304^{* \star \star}$ & 0.2569 ** & $-0.2572^{\star \star \star \star}$ & 0.99 \\
\hline 2003-04 & 0.0039 & $0.8820 * * \star$ & 0.1624 & -0.0558 & 0.88 \\
\hline 2004-05 & 0.0121 * & $0.7977^{* \star}$ & 0.0839 & -0.4087 & 0.57 \\
\hline $2005-06$ & 0.0219 & 1.8928 & -0.4781 & -0.6729 & 0.58 \\
\hline $2006-07$ & 0.0079 * & 0.7146 *** & 0.3152 & 0.5161 ** & 0.92 \\
\hline 2007-08 & -0.0015 & 0.8481 *** & $0.3381 * *$ & 0.122 & 0.87 \\
\hline $2008-09$ & -0.0233 * & 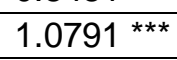 & 0.051 & -0.6256 & 0.89 \\
\hline $2009-10$ & 0.0057 & $0.6298 * * *$ & -0.2567 & 0.5381 * & 0.92 \\
\hline \multicolumn{6}{|c|}{ Multiple-year Periods } \\
\hline $2000-05$ & 0.0082 *** & $0.8417^{\text {*** }}$ & 0.2135 *** & $-0.1445 * \star \star$ & 0.88 \\
\hline 2001-06 & 0.0123 *** & 0.7836 *** & 0.0939 & -0.1287 & 0.55 \\
\hline 2002-07 & $0.0090 *$ & 0.7991 *** & 0.0239 & -0.1106 & 0.46 \\
\hline $2003-08$ & 0.0068 & $0.8160 * \star \star$ & 0.051 & -0.0383 & 0.40 \\
\hline 2004-09 & 0.0026 & 0.9478 *** & 0.1325 & 0.0789 & 0.47 \\
\hline $2005-10$ & 0.0006 & 0.9159 *** & 0.0531 & 0.0655 & 0.51 \\
\hline \multicolumn{6}{|c|}{ Other Sub-periods } \\
\hline Growth periods & 0.0000 & $0.8277^{* *}$ & 0.0845 & 0.3267 & 0.19 \\
\hline Recession periods & 0.0060 & 0.9020 *** & 0.1150 & -0.0255 & 0.56 \\
\hline Bull market & 0.0077 & $0.8284^{* *}$ & -0.1001 & 0.083 & 0.39 \\
\hline Bear market & 0.0013 & 0.8582 *** & 0.0801 & 0.1272 ** & 0.77 \\
\hline \multicolumn{6}{|c|}{ Full Period } \\
\hline $2000-10$ & 0.0035 & $0.8604^{* * \star}$ & 0.0950 & -0.0192 & 0.54 \\
\hline
\end{tabular}

Notes: 1) ${ }^{* * *}$ - statistical significance at the $1 \%$ level, $* *$ - statistical significance at the $5 \%$ level and $*$ - statistical significance at the $10 \%$ level. 2) Business cycles have been identified based on the methodology presented in Adam and Cobham (2009) and cover the following periods: Growth in $02.2000-09.2000,7.2003-6.2004$ and $10.2005-6.2007$, Recession in $10.2000-6.2003$, 7.2004 - 9.2005 and 7.2007-1.2010. 3) Bull and bear market periods have been identified using the idea of non-overlapping 'bull' and 'bear' phases based on major peaks and troughs found in the stock market indexes, presented in Gooding and O'Malley (1977) and more recently in Woodward and Anderson (2009), i.e. based on the index FTSE100 in case of this study. Bull market periods cover: $4.2003-6.2007$ and $4.2009-1.2010$ and bear market periods cover: $02.2000-3.2003$ and $7.2007-3.2009$. 
Table 7. Estimates of parameters of model:

$\operatorname{diff}\left(R_{p t}-R_{i t}\right)=\alpha_{p}+\beta_{p}\left(D Y_{p t} / D Y_{i t}\right)+\varepsilon_{t}$

in the entire period from 2000 to 2010 .

\begin{tabular}{|c|c|c|c|c|}
\hline & constant & $\begin{array}{c}D Y_{(S R I) t} / \\
D Y_{(\text {FTSE100)t }}\end{array}$ & $\begin{array}{c}D Y_{(S R I) t} / \\
D Y_{(F T S E 4 G O O D) t}\end{array}$ & $R$-squared \\
\hline $\operatorname{diff}\left(R_{S R I(\text { with_divs)t }}-R_{\text {FTSE100(with_divs)t }}\right)$ & -0.1774 & 0.2025 * & - & 0.35 \\
\hline $\operatorname{diff}\left(R_{S R I(\text { without_divs)t }}-R_{\text {FTSE100(without_divs)t }}\right)$ & -0.1628 & 0.1845 * & - & 0.31 \\
\hline $\operatorname{diff(}\left(R_{S R I(\text { with_divs)t }}-R_{F T S E 4 G O O D(\text { with_divs)t }}\right)$ & -0.1490 & - & 0.1846 * & 0.38 \\
\hline $\operatorname{diff}\left(R_{S R I(\text { without_divs)t }}-R_{F T S E 4 G O O D \text { (without_divs)t }}\right)$ & -0.1339 & - & 0.1659 * & 0.34 \\
\hline
\end{tabular}

Note: * - significant at the $10 \%$ level. 


\section{FOOTNOTES:}

${ }^{1}$ The first ethical unit trust in the UK was the Friends Provident Stewardship Fund launched in 1984 (Cowton, 1993). This and similar funds have used "the investment process as a means to change and improve the behaviour of specific corporations on social and environmental issues" (Louche and Lydenberg, working paper, p. 6).

${ }^{2}$ When constituents of the list are analysed by country, it is apparent that the country allocation was being updated over time. For example, at the time of the list being announced in 2005, Royal Dutch Shell was considered to be Dutch, however after the updates it is later listed as the UK firm. The same effect has occurred for several other companies. When this was the case, we have edited the countries to best reflect the Global-100 list at the time of data collection.

${ }^{3}$ The motivation of this study is the analysis of performance of portfolios that can be constructed by private investors based on the freely available information from the Global-100 list and since it is unlikely that such investors would engage in detailed investigations of stock size and their capitalization etc., this is also the reason why we assume that they would usually construct simple equally-weighted portfolios.

${ }^{4}$ The source of risk free rate data in the Xfi database is the return of the 3-month UK T-Bill.

${ }^{5}$ Certainty Equivalent (CEQ) returns are used in our study as an additional risk-adjusted measure in order to differentiate between risk-adjusted returns for various possible groups of investors and for their respective risk aversion levels, which naturally always vary among stock market participants (depending on many factors, such as level of wealth, aim of the investment in stocks, personal circumstances etc., among other things). Hence, the $C E Q$ measure is very useful as an additional method of evaluation of investment results in comparison with more traditional measures, such as Sharpe ratio or Treynor index, which by definition do not offer any possibility to take into account risk aversion of investors in an analysis of stock market returns. Given that the motivation of this study is the investigation of performance of SRI stocks portfolios that can be constructed by private, individual, investors (based on the freely available information in the form of the Global100 list), the analysis of the $C E Q$ returns is particularly important due to the fact that individual investors have a very broad range of risk aversion levels (much broader than institutional investors) which extends far to both sides of risk aversion interval (from very risk averse people who make investments of their private funds for e.g. retirement to very highly speculative individuals). 
6 The average annual geometric returns were calculated using the following definition: $\left(\left(1+r_{1}\right) \cdot\left(1+r_{2}\right) \cdot\left(1+r_{3}\right) \cdot \ldots \cdot\left(1+r_{n}\right)\right)^{(1 / n)}-1$, where $r_{1}, r_{2}, r_{3}, \ldots, r_{n}$ are annual returns. For example, in Table 2a the average annual geometric return for the five-year period 2000 - 2005 for the SRI portfolio is equal to $10.20 \%$ and it was computed as:

$((1+0.2422) \cdot(1-0.0245) \cdot(1-0.2081) \cdot(1+0.3665) \cdot(1+0.2393))^{(1 / 5)}-1=0.1020$ (i.e. $\left.10.20 \%\right)$.

${ }^{7}$ We also calculated MSR for the two other variants of comparisons related to results in Tables 2a and 2c. These results are not reported here due to space constraints, but are available upon request. When the SRI portfolios (with dividends) are compared against the price version of the indexes, they performed better than both FTSE100 and FTSE4GOOD also in 7 out of 10 single-year periods and, in addition, in all 5 year multiple-year periods and most other sub-periods. The advantage of SRI slightly declines on the like-to-like comparison basis for variants of SRI portfolios and indexes without dividends, but the overall pattern is similar to the results in Table 3. In any case, the modified Sharpe ratio (MSR) for the entire period is always higher and remains positive for SRI portfolios in all three cases of comparisons $(0.0627$ and 0.0082 for the variants of the SRI portfolios with and without dividends, respectively), while for both indexes FTSE100 and FTSE4GOOD it has only negative values of -0.0001 and -0.0002 (for the total return and price index versions, respectively). The comparison of SRI portfolios results with price index versions of the indexes may be relevant whenever they are used as commonly accepted market benchmarks (rather than their total return versions).

${ }^{8}$ Similar pattern of results for the CEQ measure was found for the two other variants of comparisons related to results in Tables 2a and 2c. It shows higher values of CEQ for SRI portfolios in most single-year and multiple-year sub-periods with a declining advantage over the indexes for higher risk aversion levels of the investors. These results are not reported here, but are available upon request.

${ }^{9}$ Alternative possibility to deal with time variation of beta is to estimate conditional CAPM versions of the Fama-French and Carhart models, however this methodology has been criticised due to various shortcomings (see e.g. Lewellen and Nagel, 2006 and Lewellen et al., 2010) and, therefore, we opted for a more straightforward analysis of beta estimates in sub-samples.

10 The parameters of all models in shorter sub-periods for individual years (or other shorter length periods) were estimated using: 12 monthly observations for the shortest annual periods, 60 monthly observations for the 5-year multiple periods and 61, 59, 41 and 79 monthly observations for the bull market, bear market, economic growth and recession periods, respectively. 
${ }^{11}$ Similar conclusions are reached when instead of estimation of models in shorter sub-samples we used dummy variables for the analysed sub-periods.

${ }^{12}$ These results are not reported here in details, but are available upon request.

${ }^{13}$ The pattern of betas is also very similar to the results from both Fama-French and Carhart models when beta is estimated using a simple single-factor model (estimation results are not reported but are available upon request).

${ }^{14}$ Although the small stocks effect is unlikely to be strong and materially change the overall picture which emerges from our results, we did more analysis of the small versus large stock returns and we found that when the portfolios beat the market the smaller stocks (i.e. those which are included in the Global-100 list but not in the FTSE100 index) have on average greater than the portfolio returns and when the portfolio is underperforming the market these smaller stocks are further underperforming. This means that the size effect would manifest itself, if the portfolios were capitalisation-weighted, in weaker outperformance of the SRI portfolios relative to the indexes in the periods of the SRI portfolios overperformance but also weaker underperformance in the periods when the SRI portfolios underperformed. As mentioned above, those effects are not likely, however, to be very strong due to the selection criteria of the Global-100 list, which is composed of mainly large stocks.

${ }^{15}$ For example, the Global-100 has a $75 \%$ weighting to a company’s US\$ sales to Gigajoules of total energy consumed ratio (3-year average) under the energy productivity area (Global 100, 2011). Similar use of ratios is made within the other areas listed above. The FTSE4GOOD, for example, require a high impact company under the environmental area to have in place a "policy [that] must cover the whole group and either: meet all five core indicators plus one desirable indicator, or meet four core plus two desirable indicators” (FTSE International Limited, 2010).

${ }^{16}$ These calculations are based on monthly figures from the whole period of portfolio's duration (i.e. one year between February and January in the following year). Due to space constraints they are not reported here, but are available upon request.

${ }^{17}$ We used the definition of independent variables as a ratio of DY indicators rather than a simple difference because of larger percentage variation of data in case of the ratio relative to the difference. However, we estimated also variants with differentials of DY ratios and the conclusions were quite similar, i.e. the estimates had positive signs but they were on the borderline of statistical significance (of 10\% level). 


\section{BIBLIOGRAPHY:}

Abbott, W., and Monsen, J.: 1979, 'On the Measure of Corporate Social Responsibility: Self-Reported Disclosure as a Method of Measuring Corporate Social Involvement', Academy of Management Journal 22 (3), 501-515.

Adam, C.S., and Cobham, D.: 2009, 'Using Real-Time Output Gaps to Examine Past and Future Policy Choices’, National Institute Economic Review 210 (October), 98110.

Alexander, G., and Buchholz, R.: 1978, 'Corporate Social Responsibility and Stock Market Performance’, Academy of Management Journal 21(3), 479-486.

Ali, S. and Szyszka, A.: 2006, 'Ethical Factors in Capital Market: Socially Responsible versus Unscrupulous Investment’, Argumenta Oeconomica 18(1-2), 63-87.

Ambachtsheer, J.: 2005, 'SRI: What Do Investment Managers Think?', Mercer Investment Consulting (available at: www.merceric.com).

Ambec, S. and Lanoie, P.: 2008, 'Does It Pay to Be Green? A Systematic Overview', Academy of Management Perspectives 22(4), 45-62.

Anderson, J. and Frankle, W.: 1980, 'Voluntary Social Reporting: An Iso-beta Portfolio Analysis’, Accounting Review 55(3), 467-479.

Asongu, J.J.: 2007, Strategic Corporate Social Responsibility in Practice, (Greenview Publishing Company, Greenview, IL).

Bauer, R., Derwall, J. and Otten, R.: 2007, 'The Ethical Mutual Fund Performance Debate: New Evidence from Cananda’, Journal of Business Ethics 70(2), 111-124.

Bauer, R., Koedijk, K. and Otten, R.: 2005, 'International Evidence on Ethical Mutual Fund Performance and Investment Style’, Journal of Banking and Finance 29(7), 17511767.

Bauer, R., Otten, R., and Rad, A.: 2006, 'Ethical Investing in Australia: Is There a Financial Penalty?’, Pacific-Basin Finance Journal 14(1), 33-48.

Beal, D., Goyen, M. and Phillips, P.: 2005, 'Why Do We Invest Ethically?', Journal of Investing 14(3), 66-77.

Bello, Z.: 2005, 'Socially Responsible Investing and Portfolio Diversification', Journal of Financial Research 28(1), 41-57.

Blackburn, V., Doran, M., and Shrader, C.: 1994, 'Investigating the Dimensions of Social Responsibility and the Consequences for Corporate Financial Performance', Journal of Managerial Issues 6 (2), 195-212. 
Bragdon, J.H. and Marlin, J.T.: 1972, 'Is pollution profitable?', Risk Management 19(2), 9-18.

Brown, B.: 1997, 'Stock Market Valuation of Reputation for Corporate Social Performance', Corporate Reputation Review 1(1), 76-80.

Brzeszczynski, J. and Gajdka, J.: 2008, 'Performance of High Dividend Yield Investment Strategy on the Polish Stock Market 1997-2007’, Investment Management and Financial Innovations 5(1), 87-93.

Brzeszczynski, J., Gajdka J. and Schabek, T.: 2009, 'Sustainable Investing', Polish Journal of Environmental Studies 18(5b), 56-62.

Carhart, M.M.: 1997, 'On Persistence in Mutual Fund Performance', Journal of Finance 52(1), 57-83.

Carson, R.: 1962, Silent Spring (Hougton Mifflin Company, Boston, MA).

Chegut, A, Schenk, H, and Scholtens, B.: 2011, 'Assessing SRI Fund Performance Research: Best Practices in Empirical Analysis’, Sustainable Development 19(2), 7794.

Clarkson, M.: 1995, 'A Stakeholder Framework for Analyzing and Evaluating Corporate Social Performance’, Academy of Management Review 20(1), 92-117.

Climent, F., and Soriano, P.: 2011, 'Green and Good? The Investment Performance of US Environmental Mutual Funds’, Journal of Business Ethics 103(2), 275-287.

Collison, D., Cobb, G., Power, D., and Stevenson, L.: 2009, 'FTSE4Good: Exploring Its Implications For Corporate Conduct', Accounting, Auditing and Accountability Journal 22(1), 35-58.

Consolandi, C, Jaiswal-Dale, A, Poggiani, E, and Vercelli, A.: 2008, 'Global Standards and Ethical Stock Indexes: The Case of the Dow Jones Sustainability Stoxx Index', Journal of Business Ethics 87(1), 185-197.

Cortez, M.C., Silva, F. and Areal, N.: 2009, 'The Performance of European Socially Responsible Funds’, Journal of Business Ethics 87(4), 573-588.

Cowton, C.: 1993, 'Peace Dividends: The Exclusion of Military Contractors from Investment Portfolios’, Journal of Peace Research 30(1), 21-28.

Cowton, C.: 1994, 'The Development of Ethical Investment Products', in Prindl, A. and Prodhan, B. (eds.), Ethical Conflicts in Finance, (Blackwell, Oxford).

Cowton, C.: 1998, 'Socially Responsible Investment', in Chadwick, R. (ed.), Encyclopaedia of Applied Ethics, (Academic Press, San Diego).

Cummings, L.: 2000, 'The Financial Performance of Ethical Investment Trusts: An Australian Perspective', Journal of Business Ethics 25(1), 79-92.

Davis, K.: 1973, 'The Case for and Against Business Assumption of Social Responsibilities’, Academy of Management Journal 16(2), 312-322. 
DeMiguel, V., Garlappi L., and Uppal R.: 2009, 'Optimal versus Naive Diversification: How Inefficient is the 1/N Portfolio Strategy?', Review of Financial Studies 22(5), 1915-1953.

Derwall, J., Guenster, N., Bauer, R., and Koedijk, K.: 2005, 'The Eco-efficiency Premium Puzzle', Financial Analysts Journal 61(2), 51-63.

Edmans, A.: 2011, 'Does the Stock Market Fully Value Intangibles? Employee Satisfaction and Equity Prices’. Journal of Financial Economics 101(3), 621-640.

Elton, E. and Gruber, M.: 1995, 'Efficient Markets’, in Elton, E. and Gruber, M. (eds.), Modern Portfolio Theory and Investment Analysis, (John Wiley and Sons, Hoboken, NJ).

Engle, R.F.: 1982, 'Autoregressive Conditional Heteroscedasticity with Estimates of the Variance of United Kingdom Inflation’, Econometrica 50(4), 987-1007.

Epstein, M, and Schnietz, K.: 2002, 'Measuring the Cost of Environmental and Labour Protests to Globalisation: An Event Study of the Failed 1999 Seattle WTO Talks', International Trade Journal, 16(2), 129-160.

Fama, E.F. and French, K.R.: 1992, 'The Cross-section of Expected Returns', Journal of Finance 47(2), 427-465.

Fama, E.F., and French, K.R.: 1993, 'Common Risk Factors in the Returns on Stocks and Bonds’, Journal of Financial Economics 33(1), 3-56.

Ferson, W. E. and R. W. Schadt: 1996, 'Measuring Fund Strategy and Performance in Changing Economic Conditions’, Journal of Finance 51(1), 425-46

Ferson, W. E. and V. A. Warther: 1996, 'Evaluating Fund Performance in a Dynamic Market', Financial Analysts Journal 52(6), 20-28.

Fombrun, C, and Shanley, M.: 1990, 'What's in a Name? Reputation Building and Corporate Governance Strategy, Academy of Management Journal 33(2), 233-258.

Freeman, E, and Evan, E.: 1990, 'Corporate Governance: A Stakeholder Interpretation', Journal of Behavioral Economics 19(4), 337-359.

Gil-Bazo, J., Ruiz-Verdu, P. and Santos, A.A.P.: 2010, 'The Performance of Socially Responsible Mutual Funds: The Role of Fees and Management Companies', Journal of Business Ethics 94(2), 243-263.

Glausiusz, J.: 2007, 'Better Planet: Can a Maligned Pesticide Save Lives?' Discover Magazine (November 2007), pp. 34.

Goldreyer, E. and Diltz, J.: 1999, 'The Performance of Socially Responsible Mutual Funds: Incorporating Sociopolitical Information in Portfolio Selection', Managerial Finance, 25(1), 23-36.

Gooding, A.E. and O’Malley, T.P.: 1977, 'Market Phase and the Stationarity of Beta', Journal of Financial and Quantitative Analysis 12(5), 833-857. 
Gregory, A, Matatko, J, and Luther, R.: 1997, 'Ethical Unit Trust Financial Performance: Small Company Effects and Fund Size Effects', Journal of Business Finance and Accounting 24(5), 705-725.

Gregory, A., Tharyan, R., and Christidis, A.: 2009, 'The Fama-French and Momentum Portfolios and Factors in the UK', University of Exeter Business School, Xfi Centre for Finance and Investment Paper No. 09/05. Available at: http://dx.doi.org/10.2139/ssrn.1506960

Gregory, A., Tharyan, R. and Christidis, A.: 2011, 'Constructing and Testing Alternative Versions of the Fama-French and Carhart Models in the UK', University of Exeter Business School, Xfi Centre for Finance and Investment Working Paper No. 11/02. Available at: http://dx.doi.org/10.2139/ssrn.1951831

Gregory, A., and Whittaker, J.: 2007, ' Performance and Performance Persistence of 'Ethical' Unit Trusts in the UK', Journal of Business, Finance, and Accounting 34(7), 1327-1344.

Guerard, J.: 1997, 'Is There a Cost to Being Socially Responsible in Investing', Journal of Investing 6(2), 11-19.

Halberstam, D.: 2003, 'Defining a Nation: Our America and the Sources of its Strengths’, (National Geographic Society, Washington, D.C.).

Hamilton, S., Jo, H. and Statman, M.: 1993, 'Doing Well While Doing Good? The Investment Performance of Socially Responsible Funds', Financial Analysts Journal 49(6), 62-66.

Heinkel, R., Kraus, A. and Zechner, J.: 2001, 'The Effect of Green Investment on Corporate Behavior', Journal of Financial and Quantitative Analysis 36(4), 431-449.

Hill, R., Ainscough, T., Shank, T., and Manullang, D.: 2007, 'Corporate Social Responsibility and Socially Responsible Investing: A Global Perspective', Journal of Business Ethics 70(2), 165-174.

Hill C., and Jones, T.: 1992, 'Stakeholder-agency Theory', Journal of Management Studies 29(2), 131-154.

Humphrey, J.E., and Lee, D.D.: 2011, 'Australian Socially Responsible Funds: Performance, Risk and Screening Intensity’, Journal of Business Ethics 102(4), 519535.

Humphrey, J.E., Lee, D.D. and Shen, Y.: 2012, 'Does it Cost to be Sustainable?', Journal of Corporate Finance 18(3), 626-639.

Israelsen, C.L.: 2005, 'A Refinement to the Sharpe Ratio and Information Ratio', Journal of Asset Management 5(6), 423-427.

Jagannathan, R. and Wang, Z.: 1996, 'The Conditional CAPM and the Cross-Section of Expected Returns’, Journal of Finance 51(1), 3-53. 
Jensen, M. C.: 1968, 'The Performance of Mutual Funds in the Period 1945-64', Journal of Finance 23(2), 389-449.

Jones, T.: 1995, 'Instrumental Stakeholder Theory: A synthesis of Ethics and Economics’, Academy of Management Review 20(2), 404-437.

Jones, S., van der Laan, S., Frost, S., and Loftus, J.: 2008, 'The Investment Performance of Socially Responsible Investment Funds in Australia', Journal of Business Ethics 80(2), 181-203.

Kacperczyk, M., Sialm, C. and Zheng, L.: 2005, 'On the Industry Concentration of Actively Managed Equity Mutual Funds’, Journal of Finance 60(4), 1983-2011.

Keane, S.: 1983, Stock Market Efficiency, (Philip Allan Publishers, Oxford).

Kempf, A. and Osthoff, P.: 2007, 'The Effect of Socially Responsible Investing on Portfolio Performance’, European Financial Management 13(5), 908-922.

Kinder, P., Lydenberg, S. and Domini, A.: 1994, Investing for good, Making Money While Being Socially Responsible, (Happer Business, New York, NY).

Kreander, N., McPhail, K. and Molyneaux, D.: 2004, 'An Immanent Critique of UK Church Ethical Investment', Accounting, Auditing, and Accountability Journal 17(3), 408-441.

Kurtz, L, and Di Bartolomeo, D.: 1996, 'Socially Screened Portfolios: An Attribution Analysis of Relative Performance’, Journal of Investing 5(3), 35-41.

Lenssen, G., Gasparski, W., Rok, B. and Lacy, P.: 2006, 'Corporate Social Responsibility and Competitiveness’, Corporate Governance 6(4), 1-9.

Lewellen, J., and Nagel, S.: 2006, 'The Conditional CAPM Does Not Explain Assetpricing Anomalies’, Journal of Financial Economics 82(2), 289-314.

Lewellen, J., Nagel, S., and Shanken, J.: 2010, ‘A Skeptical Appraisal of Asset Pricing Tests’, Journal of Financial Economics 96(2), 175-194.

Lowry, R.: 1991, 'Good Money. A Guide to Profitable Investing in the '9O's' New York: W.W. Norton.

Luck, C, and Pilotte, N.: 1993, 'Domini Social Index Performance', Journal of Investing 2(3), 60-62.

Mackey, A., Mackey, T.B., and Barney, J.B.: 2007, 'Corporate Social Responsibility and Firm Performance: Investor Preferences and Corporate Strategies', Academy of Management Review 32(3), 817-835.

Mallin, C., Saadouni, B. and Briston, R.: 1995, 'The Financial Performance of Ethical Investment Funds', Journal of Business Finance and Accounting 22(4), 483-496.

Malkiel, B.: 2003, 'The Efficient Markets Hypothesis and its Critics', Journal of Economic Perspectives 17(1), 59-82. 
Managi, S, Okimoto, T, and Matsuda, A.: 2012, 'Do Socially Responsible Investment Indexes Outperform Conventional Indexes?’, Applied Financial Economics 22(18), 1511-1527

Margolis, J, and Walsh, J.: 2003, 'Misery Loves Companies: Rethinking Social Initiatives by Business’, Administrative Science Quarterly 48(2), 268-305.

McGuire, J, Sundgren, A, and Schneeweis, T.: 1988, 'Corporate Social Responsibility and Firm Financial Performance’, Academy of Management Journal 31(4), 854-872.

Mill, G.: 2006, 'The Financial Performance of a Socially Responsible Investment Over Time and a Possible Link with Corporate Social Responsibility', Journal of Business Ethics 63(2), 131-148.

Minor, D.: 2007, 'Finding the [Financial] Cost of Socially Responsible Investing', Journal of Investing 16(3), 54-70.

Moskowitz, M.: 1972, 'Choosing Socially Responsible Stocks', Business and Society Review 1(1), 71-75.

Mueller, S.: 1991, 'The Opportunity Cost of Discipleship: Ethical Mutual Funds and Their Returns’, Sociological Analysis 52(1), 111-124.

Nanda, V., Wang, Z. and Zheng, L.: 2004, 'Family Values and the Star Phenomenon', Review of Financial Studies 17(3), 667-698.

Neal, R. and Cochran, P.: 2008, 'Corporate Social Responsibility, Corporate Governance and Financial Performance: Lessons from Finance’, Business Horizons 51(6), 535-540.

Orlitzky, M, Schmidt, F, and Rynes, S.: 2003, 'Corporate Social and Financial Performance: A Meta-Analysis’, Organization Studies 24(3), 403-441.

Patten, D.: 1990, 'The Market Reaction to Social Responsibility Disclosures: The Case of the Sullivan Principles Signings', Accounting, Organisations and Society 15(6), 575-587.

Renneboog, L., Horst, J.T. and Zhang, C.: 2008, 'The Price of Ethics and Stakeholder Governance: The Performance of Socially Responsible Mutual Funds', Journal of Corporate Finance 14(3), 302-322.

Rosen, B., Sandler, D. and Shani, D.: 1991, 'Social Issues and Socially Responsible Invstment Behaviour: A Preliminary Empirical Investigation', Journal of Consumer Affairs 25(2), 221-234.

Sauer, D.: 1997, 'The Impact of Social-Responsibility Screens on Investment Performance: Evidence from the Domini 400 Social Index and Domini Equity Fund', Review of Financial Economics 6(2), 23-35.

Schaltegger, S. and Figge, F.: 2001, 'Sustainable Development Funds: Progress Since the 1970s', in Bouma, J., Jeucken, M. and, Klinkers, L. (eds.), Sustainable Banking: The Greening of Finance, (Greenleaf, Sheffield). 
Scholtens, B.: 2005, 'Style and Performance of Dutch Socially Responsible Investment Funds’, Journal of Investing 14(1), 63-72.

Schroder, M.: 2007, 'Is there a Difference? The Performance Characteristics of SRI Equity Indices’, Journal of Business Finance and Accounting 34(1), 331-348.

Schueth, S.: 2003, 'Socially Responsible Investing in the United States', Journal of Business Ethics 43(3), 189-194.

Shane, P., and Spicer, B.: 1983, 'Market Response to Environmental Information Produced Outside the Firm’, Accounting Review 58(3), 521-538.

Sharpe, W.: 1966, 'Mutual Fund Performance’, Journal of Business 39(1), 119-138.

Sharpe, W.: 1994, 'The Sharpe Ratio’, Journal of Portfolio Management 21(1), 49-58.

Shiller, R.: 2005, Irrational Exuberance, (Princeton University Press, Princeton, NJ).

Social Investment Forum: 2007, '2007 Report on Socially Responsible Investing Trends in the United States, Executive summary', Social Investment Forum, (available at: www.socialinvest.org)

Sparkes, R.: 1995, The Ethical Investor, (Harper Collins, London).

Sparkes, R.: 2001, 'Ethical Investment: Whose Ethics, which Investment?', Business Ethics: A European Review 10(3), 194-205.

Sparkes, R, and Cowton, C.: 2004, 'The Maturing Of Socially Responsible Investment: A Review of The Developing Link With Corporate Social Responsibility', Journal of Business Ethics 52(1), 45-57.

Spicer, B.: 1978, 'Investors, Corporate Social Performance and Information Disclosure: An Empirical Study', Accounting Review 53(1), 94-111.

Statman, M.: 2000, 'Socially Responsible Mutual Funds', Financial Analysts Journal 56(3), 30-39.

Statman, M.: 2005, 'The Religions of Social Responsibility', Journal of Investing, 14(3), 14-22.

Statman, M.: 2008, 'Quiet Conversations: The Expressive Nature of Socially Responsible Investors’, Journal of Financial Planning 21(2), 40-46.

Ullmann, A.: 1985, 'Data in Search of a Theory: A Critical Examination of the Relationship among Social Performance, Social Disclosure and Economic Performance of U.S. Firms', Academy of Management Review 10(1-2), 540-557.

United Kingdom Social Investment Forum (UKSIF): 2000, 'Response of UK Pension Fund to the SRI Disclosure Regulation', London: UK Social Investment Forum

Waddock, S, and Graves S.: 1997, 'The Corporate Social Performance-Financial Performance Link', Strategic Management Journal 18(4), 303-319. 
Vance, S.: 1975, 'Are Socially Responsible Corporations Good Investment Risks?', Management Review 64(8) 18-24.

Visscher, S. and Filbeck, G.: 2003, 'Dividend-Yield Strategies in the Canadian Stock Market', Financial Analysts Journal 59(1), 99-106.

Weber, M.: 2008, 'The Business Case for Corporate Social Responsibility: A Company-level Measurement Approach for CSR', European Management Journal 26(4), 247-261.

Woodward, G., and Anderson, H.: 2009, 'Does Beta React to Market Conditions? Estimates of 'Bull' and 'Bear' Betas Using a Nonlinear Market Model with an Endogenous Threshold Parameter’, Quantitative Finance 9(8), 913-924.

\section{WORKING PAPERS:}

Galema, R., Scholtens, B., and Plantinga, A., 'The Cost of Socially Responsible Portfolios: Testing for Mean-Variance Spanning', working paper, University of Groningen, available at: http://ssrn.com/abstract $=1086560$

Hoepner, A.G.F., and McMillan, D.G., 'Research on "Responsible Investment": An Influential Literature Analysis Comprising a Rating, Characterisation, Categorisation and Investigation', working paper, University of St. Andrews, available at: http://ssrn.com/abstract $=1454793$

Louche, C., and Lydenberg, S., 'Socially Responsible Investment: Differences between Europe and the United States', working paper, Vlerick Leuven Gent Management School, available at:

http://www.vlerick.com/en/knowres/publications/working/2474-

VLK.html?branch=1\&language $=2$

\section{WEB PAGES:}

www.ftse.com

FTSE International Limited (2010), 'FTSE4GOOD Index Series: Inclusion Criteria', available at:

http://www.ftse.com/Indexes/FTSE4Good Index Series/Downloads/F4G Criteria.pdf

Source of 'Global 100 Most Sustainable Corporations in the World list', available at: www.global100.org

Global 100 (2011), 'Criteria and Weights: The Definitive Global Sustainability Benchmark,’ available at:

http://www.global100.org/images/stories/global100 website pdfs/criteria weights fin al.pdf 